Check for updates

Cite this: RSC Adv., 2019, 9, 34406

Received 20th July 2019

Accepted 21st August 2019

DOI: $10.1039 / c 9 r a 05605 j$

rsc.li/rsc-advances

\section{Ru(II)-N-heterocyclic carbene complexes: synthesis, characterization, transfer hydrogenation reactions and biological determination $\dagger$}

\author{
Lamia Boubakri, ${ }^{a}$ A. Chakchouk-Mtibaa, ${ }^{b}$ Abdullah S. Al-Ayed, ${ }^{c}$ L. Mansour, ${ }^{d}$ \\ Nael Abutaha, ${ }^{d}$ Abdel Halim Harrath, ${ }^{d}$ L. Mellouli, ${ }^{b}$ I. Özdemir, (iD e S. Yasar (D) e \\ and Naceur Hamdi iD *ac
}

A series of ruthenium(॥) complexes with $\mathrm{N}$-heterocyclic carbene ligands were successfully synthesized by transmetalation reactions between silver(I) $\mathrm{N}$-heterocyclic carbene complexes and $\left[\mathrm{RuCl}_{2}(p-c y m e n e)\right]_{2}$ in dichloromethane under Ar conditions. All new compounds were characterized by spectroscopic and analytical methods. These ruthenium(॥)-NHC complexes were found to be efficient precatalysts for the transfer hydrogenation of ketones by using 2-propanol as the hydrogen source in the presence of $\mathrm{KOH}$ as a co-catalyst. The antibacterial activity of ruthenium $\mathrm{N}$-heterocyclic carbene complexes $3 a-f$ was measured by disc diffusion method against Gram positive and Gram-negative bacteria. Compounds $3 d$ exhibited potential antibacterial activity against five bacterial species among the six used as indicator cells. The product $3 e$ inhibits the growth of all the six tested microorganisms. Moreover, the antioxidant activity determination of these complexes $3 a-f$, using 2,2-diphenyl-1-picrylhydrazyl (DPPH) and 2,2' azinobis-3-ethylbenzothiazoline-6-sulphonic acid (ABTS) as reagent, showed that compounds $3 \mathrm{~b}$ and $3 \mathrm{~d}$ possess DPPH and ABTS antiradical activities. From a concentration of $1 \mathrm{mg} \mathrm{ml}^{-1}$, these two complexes presented a similar scavenging activity to that of the two used controls gallic acid (GA) and butylated hydroxytoluene (BHT). From a concentration of $10 \mathrm{mg} \mathrm{ml}^{-1}$, the percentage inhibition of complexes $3 \mathrm{~b}$ and $3 \mathrm{~d}$ was respectively $70 \%$ and $90 \%$. In addition, these two Ru-NHC complexes exhibited antifungal activity against Candida albicans. Investigation of the anti-acetylcholinesterase activity of the studied complexes showed that compounds $3 \mathrm{a}, 3 \mathrm{~b}, 3 \mathrm{~d}$ and $3 \mathrm{e}$ exhibited good activity at $100 \mu \mathrm{g} \mathrm{ml}^{-1}$ and product $3 \mathrm{~d}$ is the most active. In a cytotoxicity study the complexes 3 were evaluated against two human cancer cell lines MDA-MB-231 and MCF-7. Both 3d and 3 e complexes were found to be active against the tested cell lines showing comparable activity with examples in the literature.

\section{Introduction}

Transfer hydrogenation, a potentially useful protocol for the reduction of ketones and aldehydes to their corresponding alcohols, has been extensively studied. ${ }^{\mathbf{1}}$ A large number of studies have appeared with transition metal-catalyzed

${ }^{a}$ Research Laboratory of Environmental Sciences and Technologies (LR16ESO9), Higher Institute of Environmental Sciences and Technology, University of Carthage, Hammam-Lif, Tunisia. E-mail: naceur.hamdi@isste.rnu.tn; Tel: +21698503980

${ }^{b}$ Laboratory of Microorganisms and Biomolecules, Center of Biotechnolgy of Sfax, Road of Sidi Mansour, Km 6 B.P. 1117, 3018, Sfax, Tunisia

${ }^{c}$ Chemistry Department, College of Science and Arts, Qassim University, Al-Rass, Kingdom of Saudi Arabia

${ }^{d}$ Zoology Department, College of Science, King Saud University, P.O. Box 2455, Riyadh 11451, Saudi Arabia

'Inönü University, Faculty of Science and Art, Department of Chemistry, Malatya, Turkey

$\dagger$ Electronic supplementary information (ESI) available. See DOI: 10.1039/c9ra05605j enantioselective hydrogenation of ketones using 2-propanol or formic acid under basic conditions, ${ }^{2,3}$ because the method has advantages, such as low cost, ease of handling, and high solubility of 2-propanol or formic acid as a hydrogen-donor reagent. The most active and versatile homogeneous catalytic secalcohol/ketone oxidation/reduction systems are the metalligand bifunctional ruthenium complexes developed by Noyori and co-workers. ${ }^{4-6}$ A variety of related ligands and transition metal complex catalysts have been developed for this purpose. ${ }^{7,8}$ One of these ruthenium complexes is Ru(NHC) (NHC: Nheterocyclic carbene). N-heterocyclic carbene ligands appear particularly suited to this purpose, in that their ruthenium(II) complexes possess high thermal and hydrolytic stability. ${ }^{9}$

Ligand effects are extremely important in homogeneous catalysis by metal complexes. Carbenes are both reactive intermediates and ligands in catalysis. After the first stable $\mathrm{N}$ heterocyclic carbene ligands were reported by Arduengo et al., $\mathrm{N}$-heterocyclic carbenes (NHCs) have been indispensable ligands for transition metals and homogeneous catalysis. ${ }^{\mathbf{1 0 - 1 2}}$ 

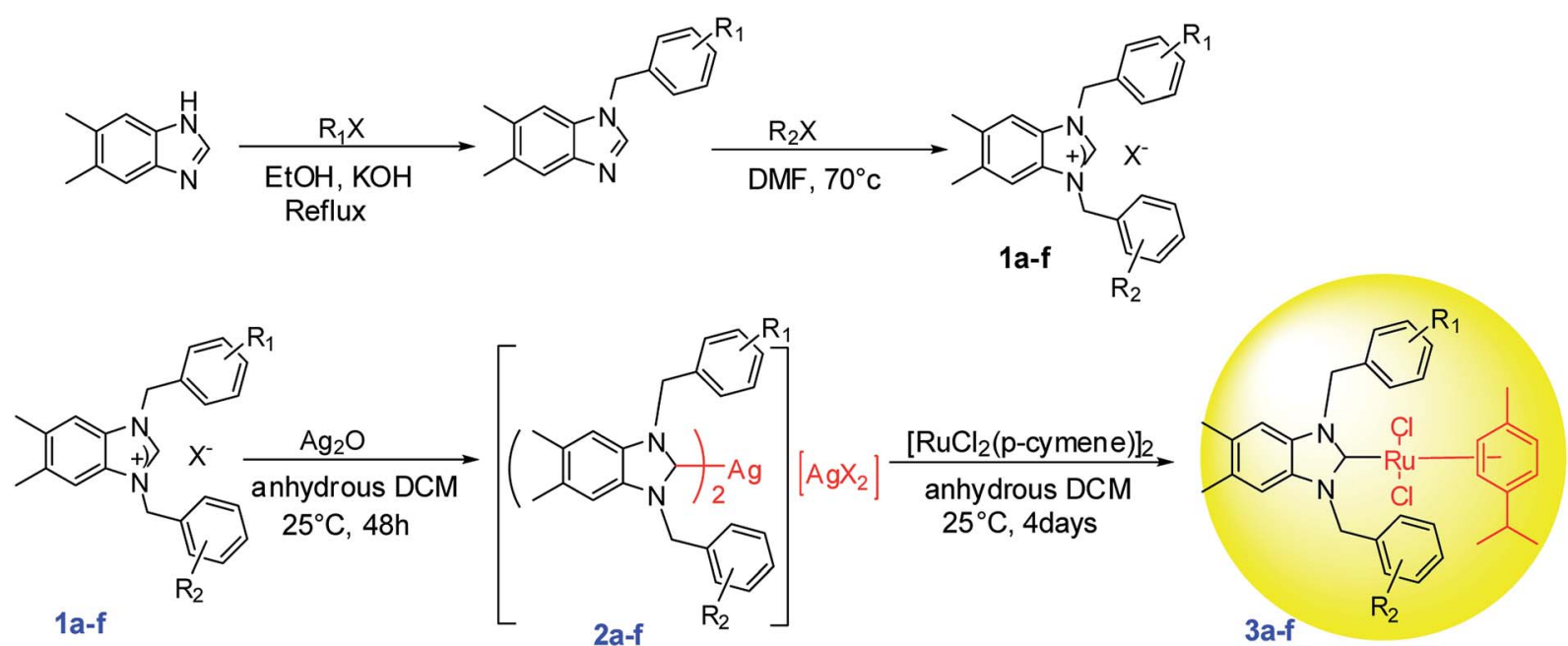

Scheme 1 Synthesis of ruthenium-NHC carbene complexes $(3 a-f)$.

Due to their topological and electronic versatility, N-heterocyclic carbene-based ligands have widespread applications not only in organometallic chemistry but also in industrial applications of homogeneous catalysis. Strong $\sigma$-donation from NHCs increases the stability of the complexes and gives complexes with advantageous properties in catalytic reactions. ${ }^{13-15}$ The first<smiles>Cc1cc(C)cc(CN2c3cc(Cl)c(C)cc3N(Cc3cc(Cl)cc(Cl)c3)C2P(Cl)(Cl)(Cl)c2cc(Cl)ccc2C(C)(C)C)c1</smiles>

$3 \mathbf{a}$ (f)

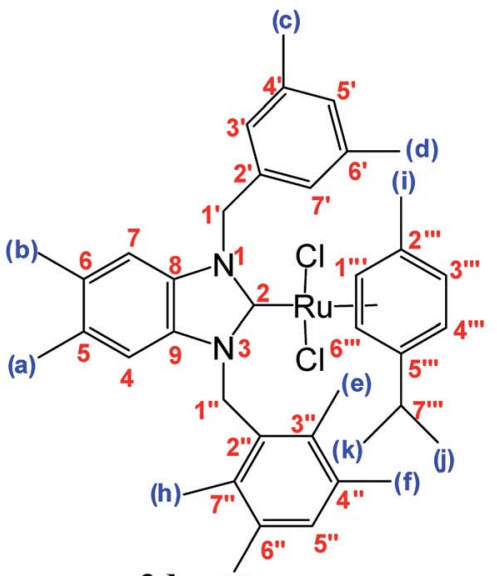

3d<smiles>Cc1cc2c(cc1C)N(Cc1ccc(Cl)cc1)C(P(Cl)(Cl)(Cl)c1ccc(Cl)cc1)N2Cc1ccc(Cl)cc1</smiles>

3b

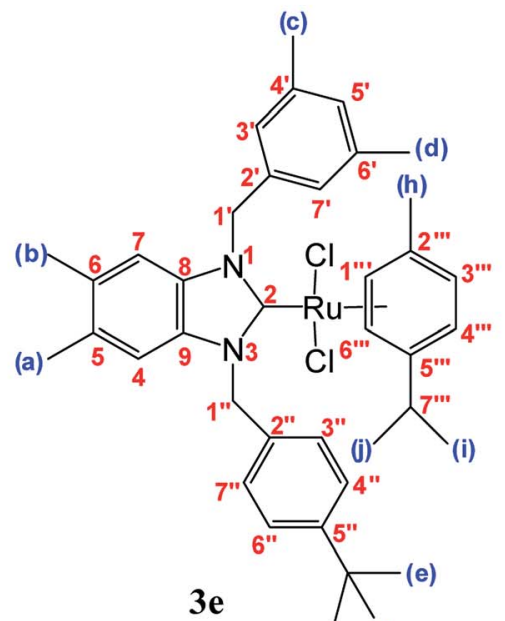

(g) (f)<smiles>Cc1ccc(C(C)C)c(C(C)(C)C)c1</smiles>

(h)

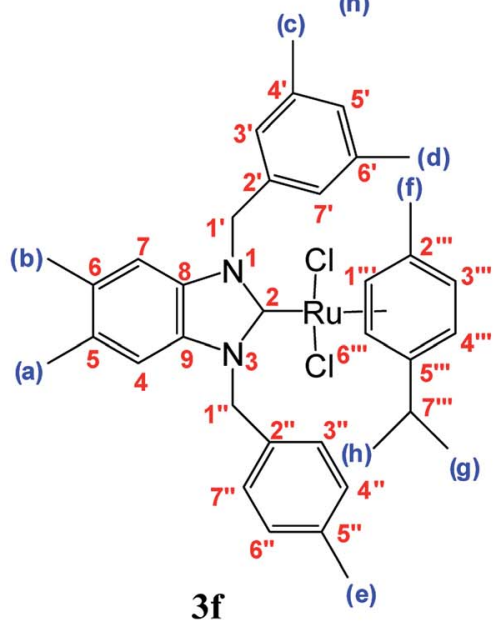

Fig. 1 Structure of ruthenium-NHC carbene complexes 3(a-f). 
catalytic applications of NHC complexes were reported by Herrmann in 1995, together with the recognition that NHCs are excellent ligands for many homogeneous catalysts. ${ }^{\mathbf{1 1}}$ Different NHC complexes and their catalytic applications have been reported by many research groups. ${ }^{16-24}$ Continued research has focused on synthesis of new functional NHC complexes. Functionality of the complexes depends on the steric and electronic effect of the ligands on the metal center. Ru-NHC complexes can be functionalized by N-substituted NHC ligands. In this context, our research group has focused on synthesis, characterization, and catalytic activity of functional $\mathrm{N}$-heterocyclic carbene ligands and their metal complexes. ${ }^{25-28}$

\section{Results and discussion}

\subsection{Preparation of $\mathbf{R u}-\mathrm{NHC}$ complexes (3a-f)}

Silver complexes of $\mathrm{N}$-heterocyclic carbenes were prepared by the addition of $\mathrm{Ag}_{2} \mathrm{O}$ to 5,6-dimethylbenzimidazolium salts solutions (1a-f) in $\mathrm{CH}_{2} \mathrm{Cl}_{2}$ under exclusion of light at room temperature (Scheme 1 and Fig. 1). White solid (in 75-90\% yield) were isolated. ${ }^{29}$ When the white solid were left in air, they began to slowly turn black. Low field signals attributed to acidic NCHN protons were not observed in the ${ }^{1} \mathrm{H}$ NMR spectra of the new Ag-NHC complexes (2a-f). This observation confirmed that the 5,6-dimethylbenzimidazolium salts were deprotonated. However, coordination of $\mathrm{N}$-heterocyclic carbene ligands to the metal center resulted in low field resonances for carbene carbon. ${ }^{29}$

All Ag-NHC complexes are widely used for the next reaction as transfer compounds. To show the feasibility of this approach for $\mathbf{2 a}-\mathbf{f}$, a series of Ru(II)-NHC complexes were synthesized in good yield as stable red solids. 3a-f were obtained by reaction of $\left[\mathrm{RuCl}_{2}(p \text {-cymene })\right]_{2}$ with a solution of $2 \mathbf{a}-\mathbf{f}$ in the dark at room temperature (Scheme 1). The air and moisture-stable ruthenium $\mathrm{N}$-heterocyclic carbene complexes (3a-f) isolated in high purity after recrystallization with DCM/ether, were soluble in solvents such as dichloromethane, chloroform, toluene, and tetrahydrofurane and insoluble in nonpolar solvents (Fig. 1). ${ }^{30}$

The ruthenium-NHC complexes 3a-f were characterized by NMR $\left({ }^{1} \mathrm{H}\right.$ and $\left.{ }^{13} \mathrm{C}\right)$, IR, and DART-TOF mass spectrometry. The ${ }^{1} \mathrm{H}$-NMR spectra of complex 3 a was recorded in $\mathrm{CDCl}_{3}$ at room temperature. Here, the proton $\mathrm{H}_{7^{\prime \prime \prime}}$ of the isopropyl group of $p$ cymene was seen as a multiplet at $2.62 \mathrm{ppm}$ (Fig. 2).

The aromatic protons appeared between 5.54 and $6.91 \mathrm{ppm}$ as a multiplet while methylic protons appeared between 1.14 and $2.30 \mathrm{ppm}$ as singlets. In the ${ }^{1} \mathrm{H}-\mathrm{NMR}$ spectra of $3 \mathrm{a},\left(\mathrm{NCH}_{2}\right)$ was resonated at 5.29 and $5.05 \mathrm{ppm}$ as a doublet.

The spectra of these products in $\mathrm{CDCl}_{3}$ supported the successful formation of the ruthenium complexes because of the absence of NCHN signal proton in a downfield for 2-3.

The ${ }^{1} \mathrm{H}$ and ${ }^{13} \mathrm{C}$ NMR spectra of these new complexes $(\mathbf{3 a}-\mathbf{f})$ are consistent with the proposed formula. ${ }^{13} \mathrm{C}\left\{{ }^{1} \mathrm{H}\right\}$ NMR spectra prove an increasing downfield shift of the characteristic peak of the carbenic carbon resonance from $2 \mathbf{a}-\mathbf{f}$ to $3 \mathbf{a}-\mathbf{f}$ : for example, the ${ }^{13} \mathrm{C}\left\{{ }^{1} \mathrm{H}\right\} \mathrm{N}-\mathrm{C}-\mathrm{N}$ shifts of $\mathbf{3 a}$ displays as a singlet at $188.8 \mathrm{ppm}$ which confirmed the transmetallation between silver and ruthenium (Fig. 3). ${ }^{31}$

The results of the mass spectrometry analyses are proof verification of the synthesized compounds (Fig. 4).

The fragmentation leading to the $m / z=279$ and $m / z=343$ ions can occur by the mechanisms shown in Scheme 2 .

\subsection{Transfer hydrogenation}

The transfer hydrogenation process, which involves hydrogen transfer from a donor to an acceptor, has become one of the most important synthetic routes for producing alcohols from

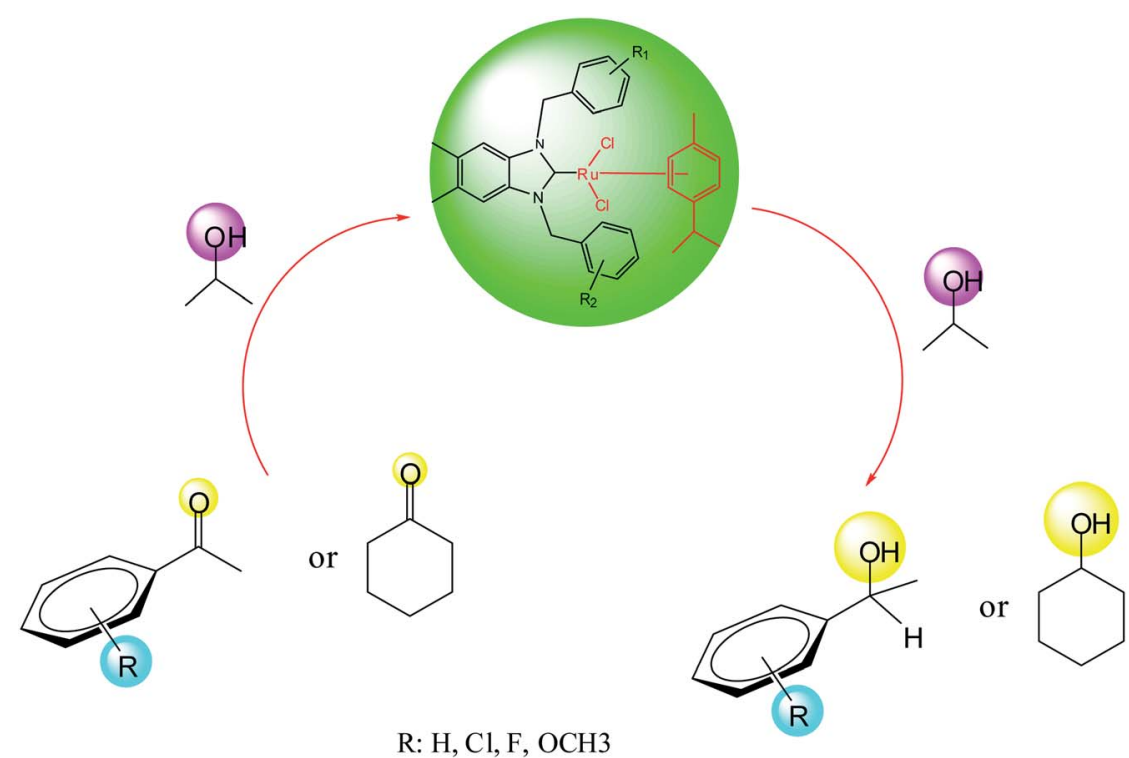




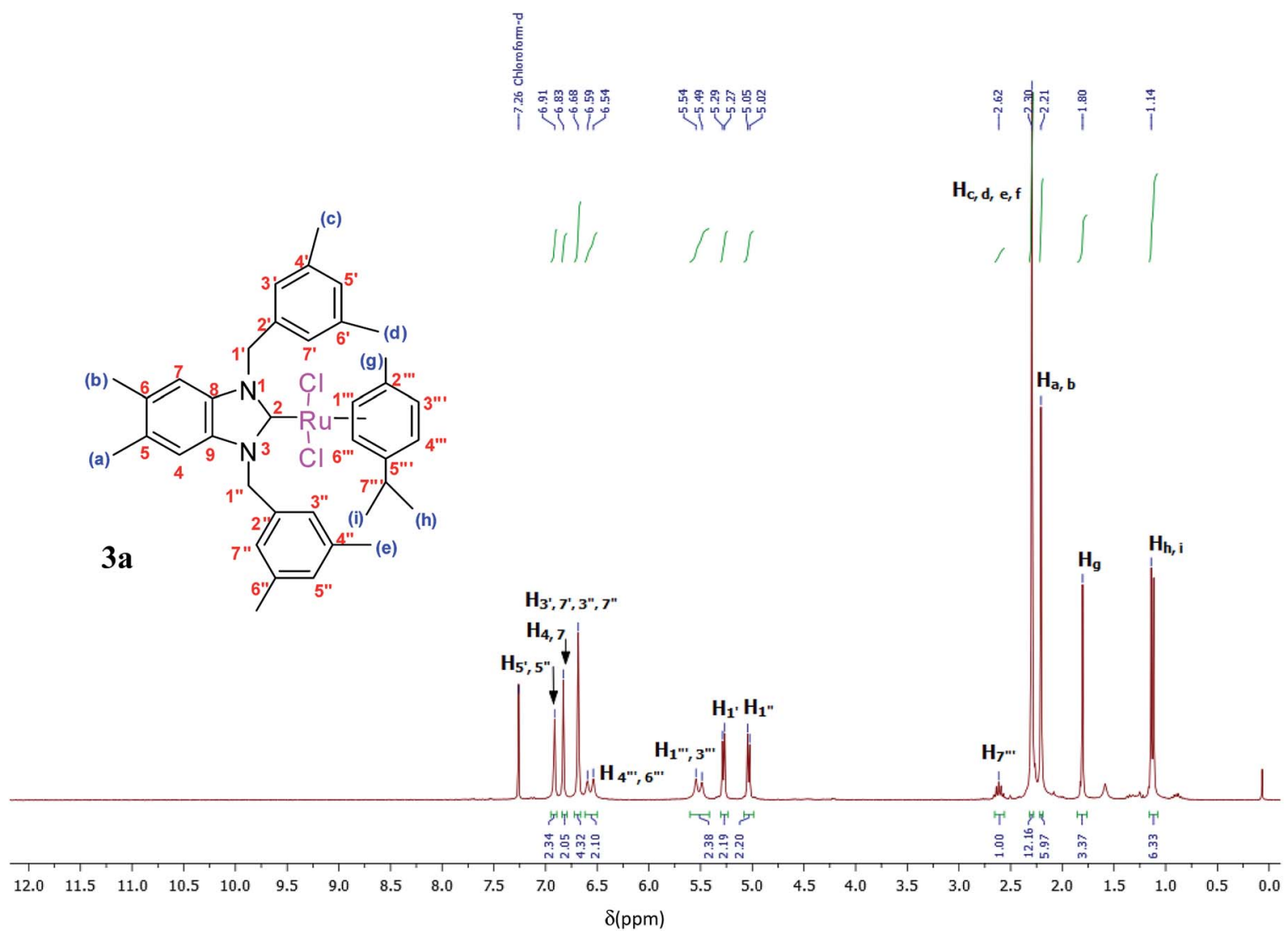

Fig. $2{ }^{1} \mathrm{H}$ NMR spectra of Ru(॥)-N-heterocyclic carbene complexes $3 a\left(\mathrm{CDCl}_{3}, 300 \mathrm{MHz}\right)$.

ketones. ${ }^{32}$ Non-toxic reagents, green solvents and mild reaction conditions are remarkable features of transfer hydrogenation reactions. ${ }^{33}$ Transition-metal catalyzed transfer hydrogenation using 2-propanol and $\mathrm{KOH}$ as a hydrogen source and promoter respectively, has become an efficient method in organic synthesis as illustrated by several useful applications reported in recent years. ${ }^{34}$ The reaction conditions for this important process are easy to handle (moderate boiling point $82{ }^{\circ} \mathrm{C}$ ), inexpensive, relatively mild and environmentally benign. ${ }^{30}$

As part of our ongoing investigation into novel functionalized NHC ligands as the supporting environment for metal complexes and their application in catalysis. We herein report a series of catalytic transfer hydrogenation reactions employing the ruthenium-NHC complexes to discover their benefits. The transfer hydrogenation reactions are very susceptible to the type of the base and its concentration. ${ }^{31}$ As the starting point, the performance of the catalysts in the transfer hydrogenation was screened by using acetophenone as a model substrate. ${ }^{30,31,33}$ Previously, our laboratory reported the application of ruthenium-NHC complexes in the transfer hydrogenation of ketones. ${ }^{30}$ According to the literature, in a typical experiment, we dissolved the preformed, isolated crystalline catalyst $(0.005$ $\mathrm{mmol})$ in 2-propanol. After the catalysts had completely dissolved, ketone $(0.5 \mathrm{mmol})$ and a $\mathrm{KOH}(2 \mathrm{mmol})$ were added and the reaction was performed at $80{ }^{\circ} \mathrm{C}$ in $1 \mathrm{~h}$.
In this context, we investigated the nature of the catalysts and the substrate that could impact on yield in the transfer hydrogenation reaction. Catalyst performance depends on the nature of substrates, the behavior of the ligands in the complexes, and concentration of the catalyst. Electrophilic effect of the substrate, nature of the catalysts, donor function, and flexibility of the backbone in the NHC ligands can be responsible for activity of the complexes. Steric and electronic properties of the substrates also affect conversions. Acetophenone and $p$-chloroacetophenone reacted very cleanly and turned into corresponding alcohol in good yields (Table 1, entries 1-6). However, 3b complex exhibited the lowest catalytic activity with all ketones. This low catalytic activity was attributed to structure of complex $\mathbf{3 b}$, presumably due to decreased steric bulk around the metal or lower electron donation provided by the carbene ligands (Table 1, entries 2, 5, 8, 11 and 14). When $p$-methoxyacetophenone was used as substrate, low yield was observed on the transfer hydrogenation reaction catalysed by 3a-c (Table 1, entries 10-12). We are of the opinion that the nature of substrate can also give rise to low yield. Substrates bearing electron-withdrawing groups (Table 1, entries 4-9) were reduced to secondary alcohols in better yield than substrates bearing electron-donating groups (Table 1, entries 10-12). Similarly, with only $0.5 \mathrm{~mol} \%$ of the same catalysts, it was possible to hydrogenate cyclohexanone and obtain 


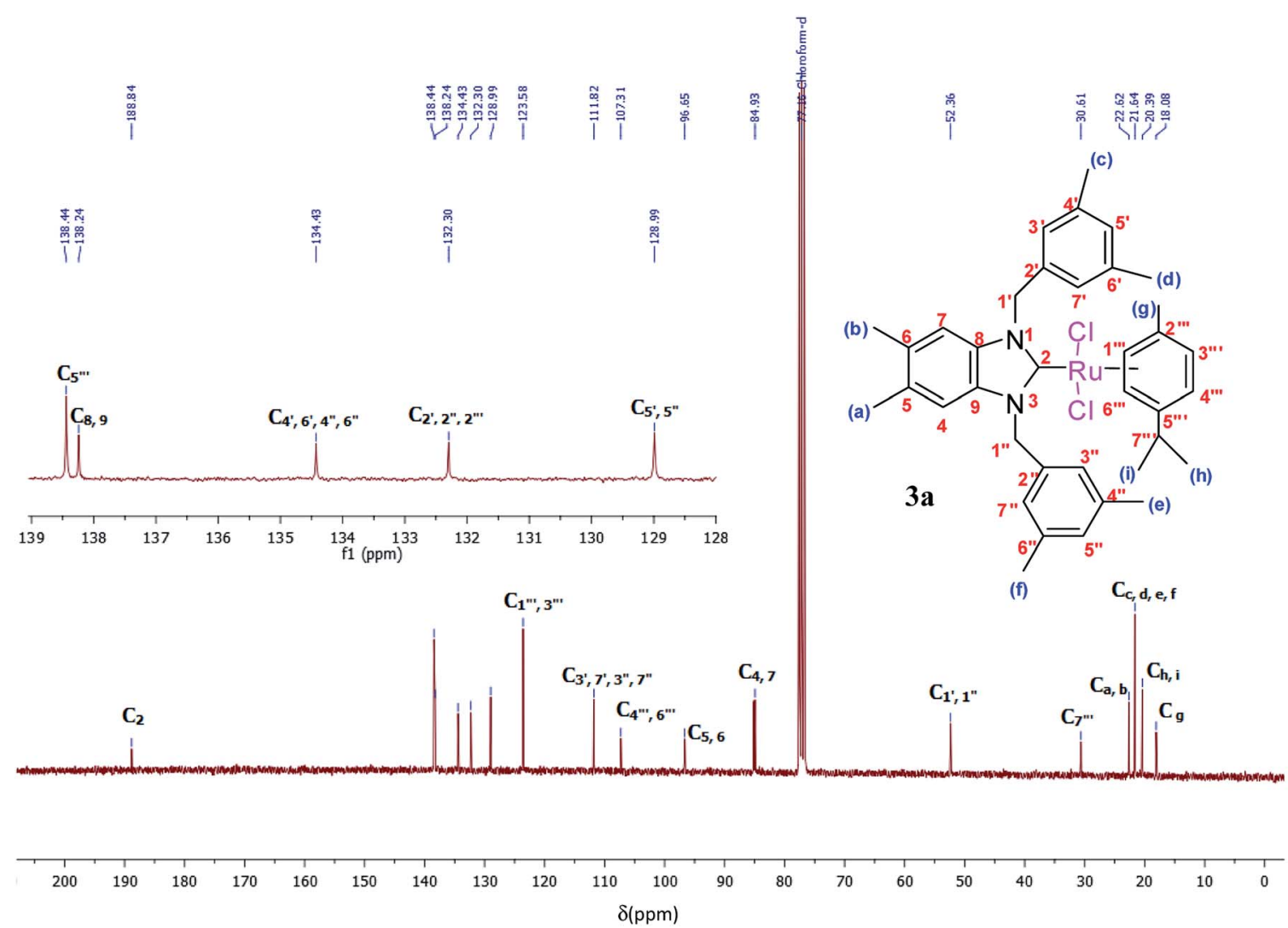

Fig. $3{ }^{13} \mathrm{C}$ NMR spectra of Ru(॥)-N-heterocyclic carbene complexes $3 a\left(\mathrm{CDCl}_{3}, 75 \mathrm{MHz}\right)$.

the corresponding alcohols with the highest yields (Table 1, entries 13-15).

\section{Biological activities}

\subsection{Antibacterial activity}

The synthesized complexes were examined in vitro for their antibacterial activity using the well diffusion method (Fig. 5). Ampicillin (AMC) was used as standard control drugs for antibacterial activity. The ruthenium-NHC complexes (3a-f) were evaluated against three Gram-positive bacteria (Micrococcus luteus LB14110, Listeria monocytogenes ATCC19117, Staphylococcus aureus ATCC6538) and three Gram-negative bacteria (Salmonella typhimurium ATCC14028, Pseudomonas aeruginosa ATCC 9189, Escherichia coli). The obtained antibacterial activity is presented in Fig. 6 and Table 2.

Globally, all complexes tested showed an important antibacterial activity against the Micrococcus luteus LB14110. Although complex 3d presents the highest inhibitory effect. In addition, 3e inhibit the growth of Gram-positive and Gram-

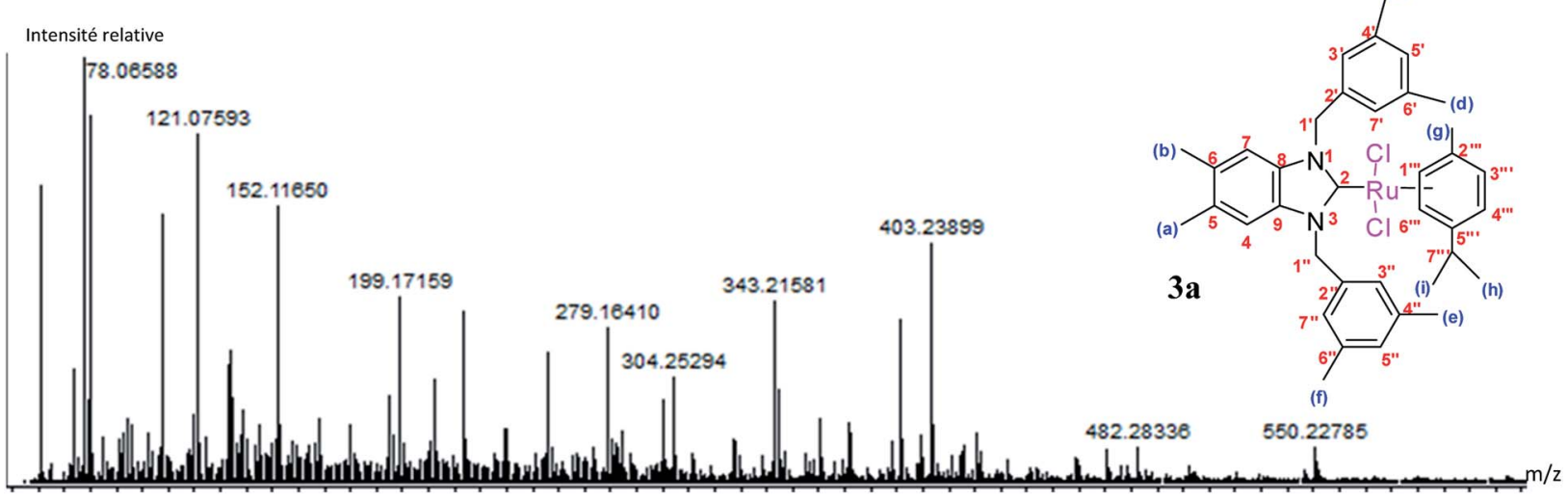

Fig. 4 DART-TOF-MS of Ru(I)-N-heterocyclic carbene complexes 3a. 
<smiles></smiles>

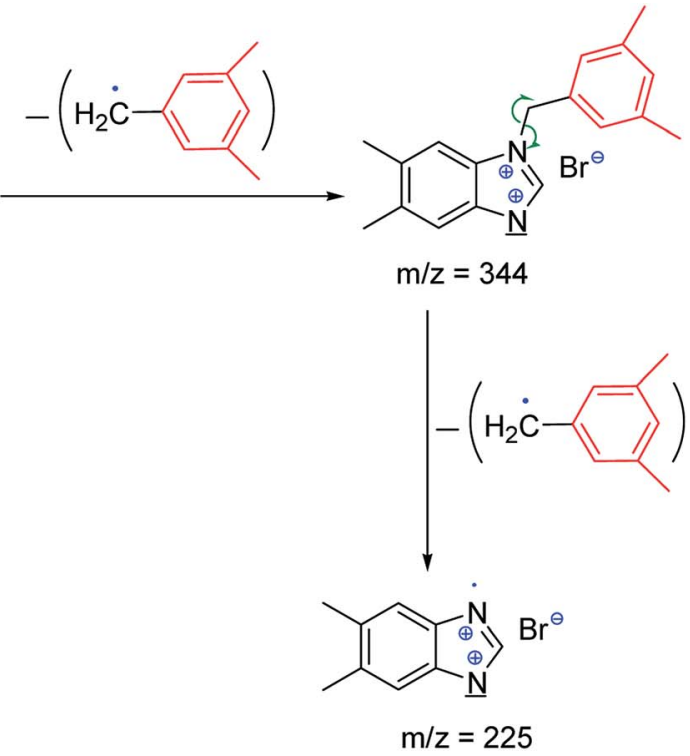

Scheme 2 Mechanism of fragmentation leading to peaks $m / z=225$.

negative bacteria in high and low concentrations. In contrast, the other complexes show no activity against $E$. coli.

The antibacterial activity of ruthenium- $\mathrm{N}$-heterocyclic carbene complexes (3a-f) was reported in terms of the MIC values, defined as the lowest concentration of an antibacterial that visibly inhibits the growth of the bacteria after an overnight incubation. The MICs values complexes $\mathbf{3}$ were determined against the two Gram positive bacteria Micrococcus luteus LB 14110 and Listeria monocytogenes ATCC 19117 and the Gramnegative bacterium Salmonella typhimurium ATCC 14028. As shown in Table 3, the MICs values range from $0.0195-0.625 \mathrm{mg}$ $\mathrm{ml}^{-1}$ for Micrococcus luteus LB 14110; $0.0781-5 \mathrm{mg} \mathrm{ml}^{-1}$ for Listeria monocytogenes ATCC 19117 and Salmonella typhimurium ATCC 14028. The most active compound was $3 \mathbf{d}$ which presents

Table 1 Transfer hydrogenation of ketones catalyzed by ruthenium-NHC complexes $3(\mathrm{a}-\mathrm{c})^{a}$

Entry

${ }^{a}$ Reaction conditions: $0.005 \mathrm{mmol} \mathrm{Ru}-\mathrm{NHC}$, i-PrOH $(5 \mathrm{ml})$, $\mathrm{KOH}(2 \mathrm{mmol})$, substrate $(0.5 \mathrm{mmol}), 80{ }^{\circ} \mathrm{C}, 1 \mathrm{~h} .{ }^{b}$ Conversions are based on corresponding ketones. 


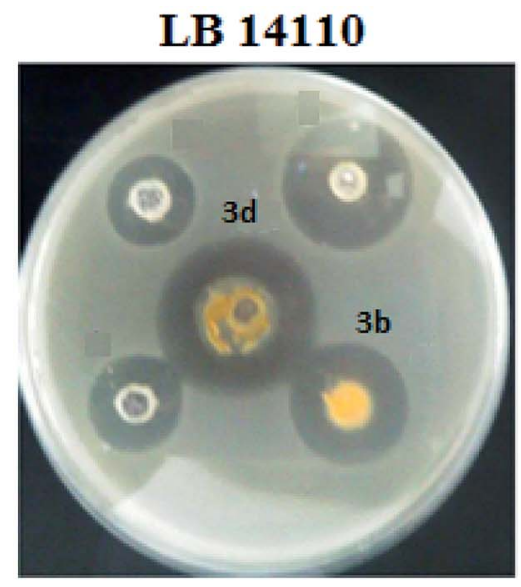

ATCC 14028

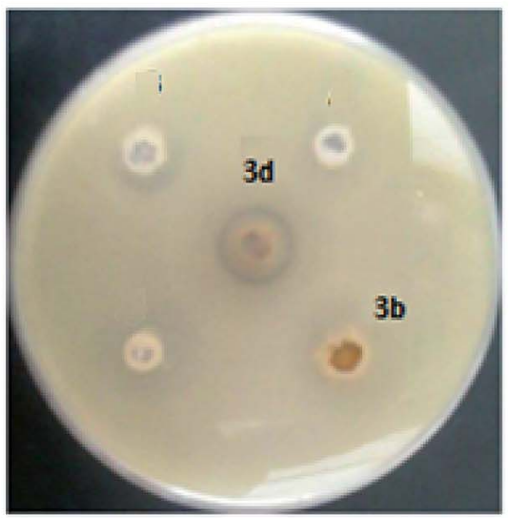

ATCC 19117

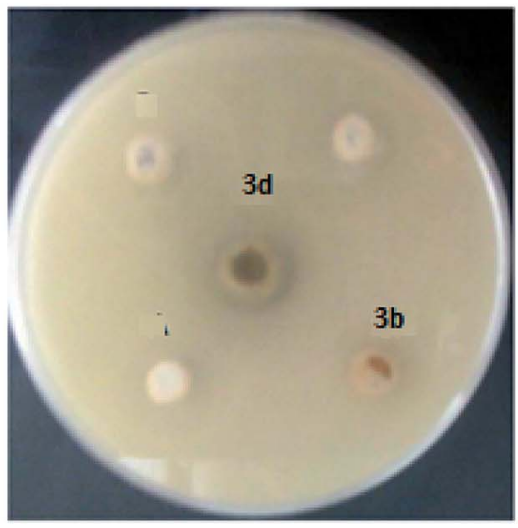

ATCC 49189

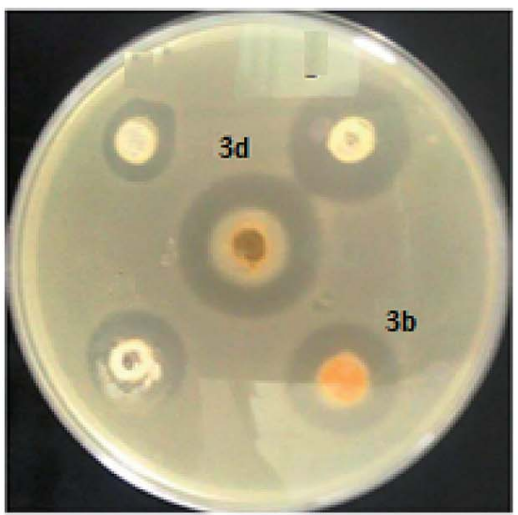

ATCC 6538

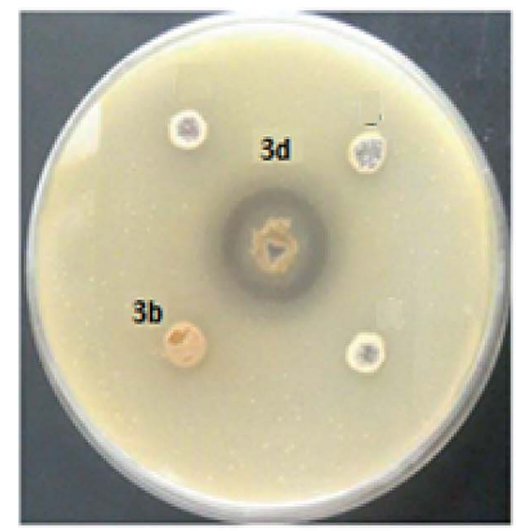

E.Coli

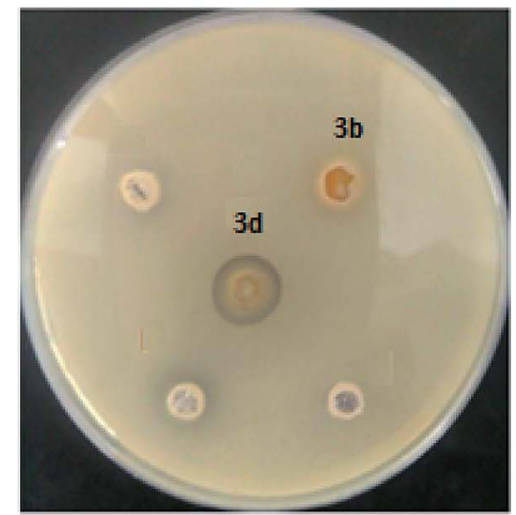

Fig. 5 Zone of inhibition of Ru-NHC complexes (3a-f).

against Salmonella typhimurium ATCC 14028 the lowest MIC value $\left(0.0781 \mathrm{mg} \mathrm{ml}^{-1}\right)$ than the used standard (ampicillin). Thus, the best activity was recorded for this complex with MIC values of $0.0195 \mathrm{mg} \mathrm{ml}^{-1}$ against Micrococcus luteus LB14110. Complex 3e also has MIC values of $0.0781 \mathrm{mg} \mathrm{ml}^{-1}$ against Listeria monocytogenes ATCC 19117.

\subsection{Antioxidant activity}

3.2.1. Antiradical test: DPPH. The proton radical scavenging action is known to be one of the various mechanisms for antioxidation. DPPH (1,1-diphenyl-2-picrylhydrazyl) is one of the compounds that possess a proton free radical and shows a characteristic absorption at $517 \mathrm{~nm}$ (purple). When DPPH encounters proton radical scavengers, its purple color would fade rapidly. Among all free radicals, the hydroxyl radical is by far the most potent and therefore the most dangerous oxygen metabolite which would result in cell membrane disintegration, membrane protein damage, DNA mutation and further initiate or propagate the development of many diseases. Elimination of this radical is one of the major aims of antioxidant administration. ${ }^{35}$ Current research has shown that some antioxidants could act as the inducers of DNA damage response, which leads to cell death. ${ }^{36}$ In present study, the scavenging activity of the synthesized Ru-NHC complexes (3a- f) on the DPPH radical were investigated. As shown in Fig. 7, the complexes $\mathbf{3 b}$ and $\mathbf{3 d}$ present a higher antioxidant activity than other complexes which no antioxidant activity was observed. From the results, we can see that, within the range of tested concentration, the average suppression ratios of DPPH increase along with the increase of the complex concentration (Fig. 7). Concerning complexes $\mathbf{3 b}$ and $\mathbf{3 d}$, from a concentration of $1 \mathrm{mg} \mathrm{ml}^{-1}$, the scavenging activity was very similar to that of the two used control gallic acid (GA) and butylated hydroxytoluene (BHT) known as very good antioxidant compounds.

3.2.2. Antiradical test: ABTS. The dark blue color of ABTS (ammonium salt of 2,2'-azinobis-3-ethylbenzothiazoline-6sulphonic acid) turns very dark blue and may even become colorless if there are radical scavengers free. This discoloration is based on the oxidation of the conjugated organic structure in radical cation $\mathrm{ABTS}^{\circ+}$. To carry out the ABTS trapping test, $20 \mu \mathrm{l}$ of the synthesized products were added to $18 \mu \mathrm{l}$ of the prepared $\mathrm{ABTS}^{+}$solution, while stirring vigorously for 30 seconds. The resulting solution was mixed with ethanol and ultrapure water $(5: 5) \mathrm{v} / \mathrm{v}$. Tubes containing volumes of equivalent amounts of the different complexes are incubated under incubation and controlled for $6 \mathrm{~min}$ in the dark. After a sweep, the wavelength of the 


\section{Listeria monocytogenes ATCC 19117}

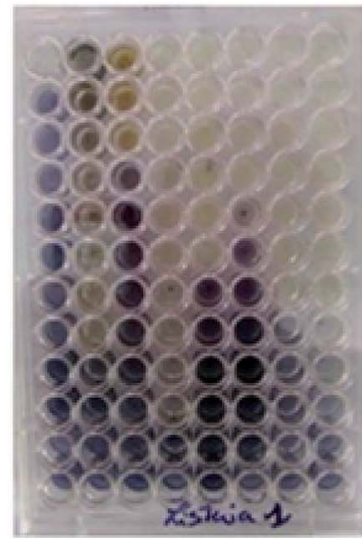

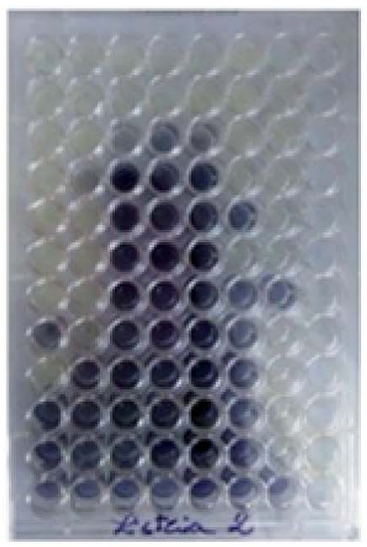
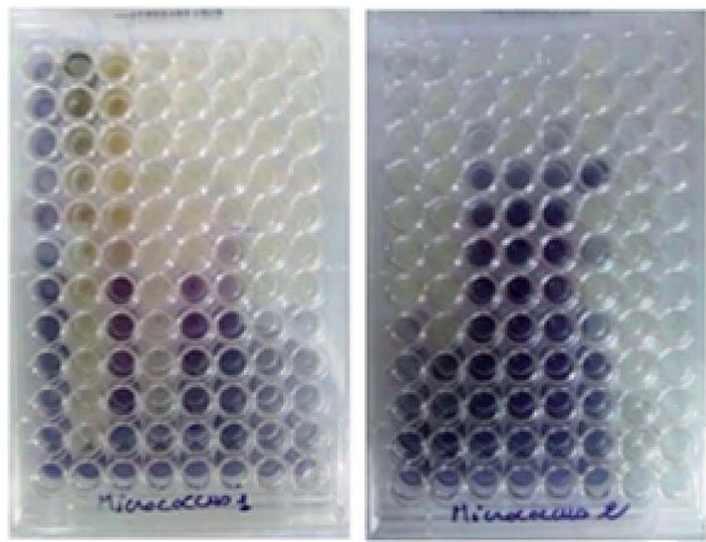

\section{Salmonella typhimurium ATCC 14028}
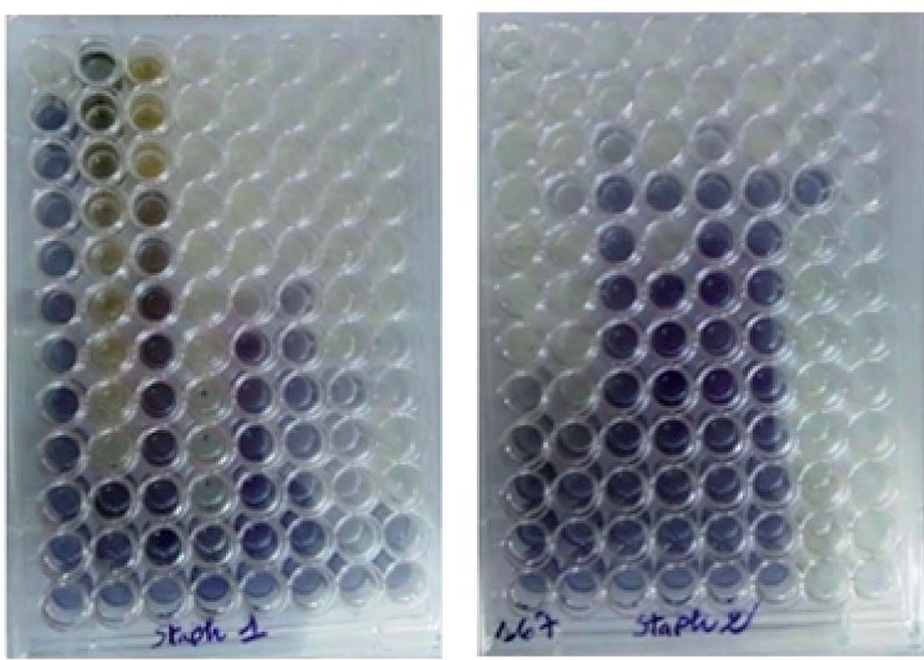

Fig. 6 The method of determining the MIC.

work chosen for the evaluation of the antiradical activity was set at $734 \mathrm{~nm}$. In order to explore the experimental results obtained, it is necessary to calculate the percentages of inhibition of the free radical $\mathrm{ABTS}^{+}$according to the following formula:

$$
\mathrm{AAO} x \%=\left[\left(A_{\mathrm{c}}-A_{\mathrm{e}}\right) / A_{\mathrm{c}}\right] \times 100
$$

$A_{\mathrm{c}}$ : absorbance of control; $A_{\mathrm{e}}$ : absorbance of the sample.

As shown in Fig. 8, complexes $\mathbf{3 b}$ and 3d present a high antioxidant activity. Concerning the compound $\mathbf{3 b}$, from a concentration of $10 \mathrm{mg} \mathrm{ml}^{-1}$ the percentage inhibition was in order to $70 \%$. For compound $\mathbf{3 d}$, the percentage inhibition was in order to $90 \%$.

\subsection{Antifungal activity}

Fungal pathology has increased in recent years due to the increase in deep, visceral and septicemic mycotic sites. The former are caused by fungi that are widespread in nature, usually saprophytic, becoming pathogenic only under certain conditions: increasing use of broad-spectrum antibiotics, patients with AIDS; we talk about iatrogenic mycoses. They are caused by so-called opportunistic fungi that are either levuriform (Candida, Cryptococcus) or filamentous (Aspergillus, Cephalosporium). ${ }^{37}$ The development of antifungals comes up against obstacles such as the weak fungicidal activity in vivo compared to the results in vitro and the poor diffusion through the very thick wall of the mushrooms because of its composition (chitin, phospholipids, and sterols); these constituents are absent in bacteria, which explains why most antibacterial antibiotics are not antifungals.

To evaluate the antifungal activity of the Ru-NHC complexes (3a-f) with respect to the Candida albicans strain, the solid medium diffusion method was carried out (Fig. 9). As shown in Table 4, the complexes 3a, 3c, $\mathbf{3 e}$ and $\mathbf{3 f}$ are completely inactive against Candida albicans. The compounds 3b and 3d present a high antifungal activity. The most active compound was $\mathbf{3 d}$ which presents against Candida albicans the highest diameter of growth inhibition zone with a value of the order of $34 \pm 0.18 \mathrm{~mm}$. 
Table 2 Antibacterial activity of the synthesized Ru-NHC complexes (3a-f)

\begin{tabular}{|c|c|c|c|c|c|c|}
\hline \multirow[b]{3}{*}{ Compounds } & \multicolumn{6}{|c|}{ Microorganism indicator } \\
\hline & $\begin{array}{l}\text { Micrococcus } \\
\text { luteus }\end{array}$ & $\begin{array}{l}\text { Listeria } \\
\text { monocytogenes }\end{array}$ & $\begin{array}{l}\text { Staphylococcus } \\
\text { aureus }\end{array}$ & $\begin{array}{l}\text { Salmonella } \\
\text { typhimurium }\end{array}$ & $\begin{array}{l}\text { Pseudomonas } \\
\text { aeruginosa }\end{array}$ & \\
\hline & LB 14110 & ATCC 19117 & ATCC 6538 & ATCC 14028 & ATCC 49189 & E. coli \\
\hline $3 \mathbf{a}$ & $30 \pm 0.5$ & $16 \pm 0.2$ & - & $16 \pm 0.2$ & - & - \\
\hline $3 \mathbf{b}$ & $20 \pm 0.4$ & - & - & - & $20 \pm 0.2$ & - \\
\hline $3 \mathrm{c}$ & $18 \pm 0.2$ & $20 \pm 0.4$ & - & $14 \pm 0.7$ & - & - \\
\hline $3 d$ & $30 \pm 0.32$ & $18 \pm 0.1$ & $22 \pm 0.4$ & $18 \pm 0.1$ & $26 \pm 0.11$ & - \\
\hline $3 e$ & $23 \pm 0.3$ & $16 \pm 0.5$ & $17 \pm 0.3$ & $16 \pm 0.6$ & $16 \pm 0.22$ & $15 \pm 0.2$ \\
\hline $3 f$ & - & - & - & - & - & - \\
\hline
\end{tabular}

Table 3 Minimum Inhibitory Concentrations (MICs) expressed in mg $\mathrm{ml}^{-1}$

\begin{tabular}{|c|c|c|c|}
\hline \multirow[b]{3}{*}{ Compounds } & \multicolumn{3}{|c|}{ Minimum inhibitory concentrations $\left(\mathrm{mg} \mathrm{ml}^{-1}\right)$} \\
\hline & Micrococcus luteus & $\begin{array}{l}\text { Listeria } \\
\text { monocytogenes }\end{array}$ & $\begin{array}{l}\text { Salmonella } \\
\text { typhimurium }\end{array}$ \\
\hline & LB 14110 & ATCC 19117 & ATCC 14028 \\
\hline $3 \mathbf{a}$ & 0.039 & 0.3125 & 2.5 \\
\hline $3 \mathbf{b}$ & 0.625 & 5 & 5 \\
\hline $3 \mathbf{c}$ & 0.039 & 1.25 & 2.5 \\
\hline 3d & 0.0195 & 0.1562 & 0.0781 \\
\hline $3 \mathbf{e}$ & 0.0195 & 0.0781 & 1.25 \\
\hline $3 f$ & - & - & - \\
\hline Ampicillin & 0.004 & 0.002 & 0.625 \\
\hline
\end{tabular}

\subsection{Acetylcholinesterase inhibition}

The acetylcholinesterase enzyme (AChE) is an attractive target for the rational drug design and for the discovery of mechanism-based inhibitors because of its role in the hydrolysis of the neurotransmitter acetylcholine (ACh). The pathogenesis of Alzheimer's disease (AD) has been linked to a deficiency in the brain neurotransmitter acetylcholine. Subsequently, acetylcholinesterase inhibitors (AchEIs) were introduced for the symptomatic treatment of $\mathrm{AD},{ }^{38,39}$ and other possible therapeutic applications in the treatment of
Parkinson's disease, senile dementia, and ataxia, among others. ${ }^{40}$ The prevailing view has been that the efficacy of AchEIs is attained through their augmentation of acetylcholinemedicated neuron to neuron transmission. However, AchEIs also protect cells from free radical toxicity and $\beta$-amyloid induced injury and increased production of antioxidants.

The results presented in Table 5 show that the $\mathbf{3 d}$ complex is the most potent inhibitor against AchE. This good activity is confirmed by a value of the percentage inhibition of the order of $47.1 \%$. However, the $3 \mathbf{c}$ and $\mathbf{3 f}$ complexes are completely inactive and the other Ru-NHC complexes exhibit anti-AchEI activity.

\subsection{Anticancer activity}

3.5.1. Cytotoxicity assay. Cytotoxicity of compounds was assessed using MTT assay on MDA-MB-231 cells and MCF7 cells as carried out previously (Song et al., 2010). ${ }^{41}$ In brief, cells were cultured into 96-well plates (Corning, USA) at a density of $5 \times$ $10^{5}$ cells per well in $200 \mu \mathrm{l}$ medium. After $24 \mathrm{~h}$, cells were treated with different concentrations $\left(10,5,2.5,1 \mu \mathrm{g} \mathrm{ml} \mathrm{m}^{-1}\right)$ of compounds and further incubated for $48 \mathrm{~h}$ to evaluate the cytotoxicity of compounds. At the end of incubation period, 20 $\mu \mathrm{l}$ MTT solution was added to each well and cells were further incubated for $2 \mathrm{~h}$ at $37^{\circ} \mathrm{C}$. Finally, the media were aspirated and then $200 \mu \mathrm{l} 0.1 \% \mathrm{HCl}-\mathrm{MeOH}$ was added to dissolve formazan crystals. The OD value was read at $490 \mathrm{~nm}$ on a microplate reader (Thermo Multiskan FC, China). $\mathrm{MeOH}$-treated cells were
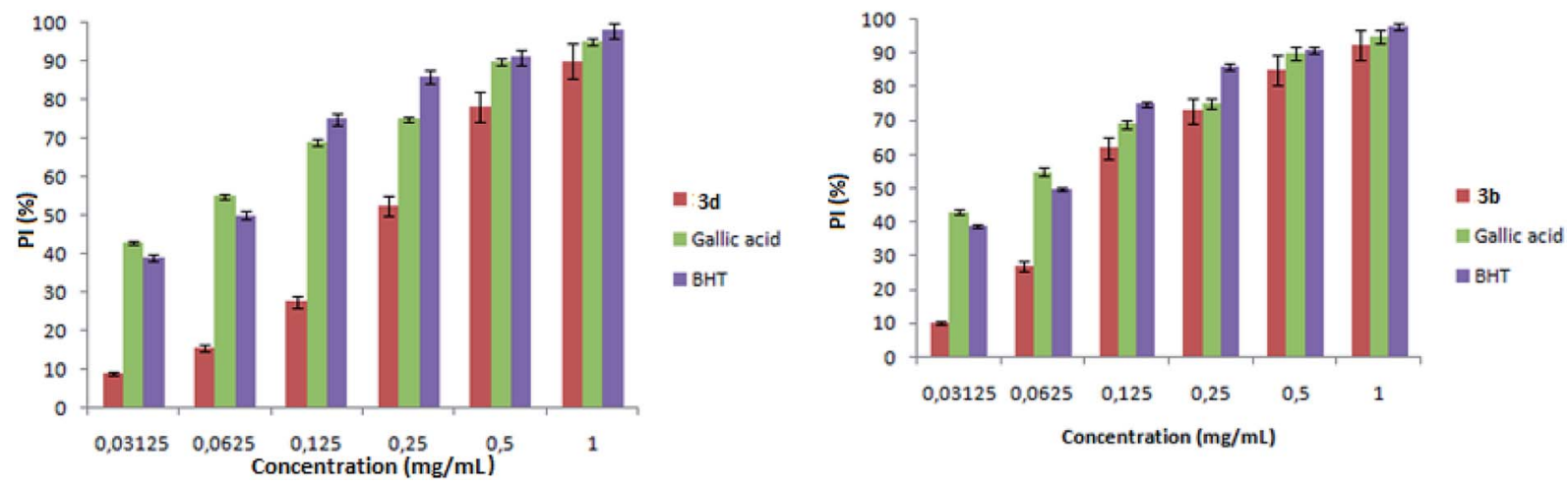

Fig. 7 Scavenging activity of compounds $3 b$ and $3 d$ on DPPH radicals. 

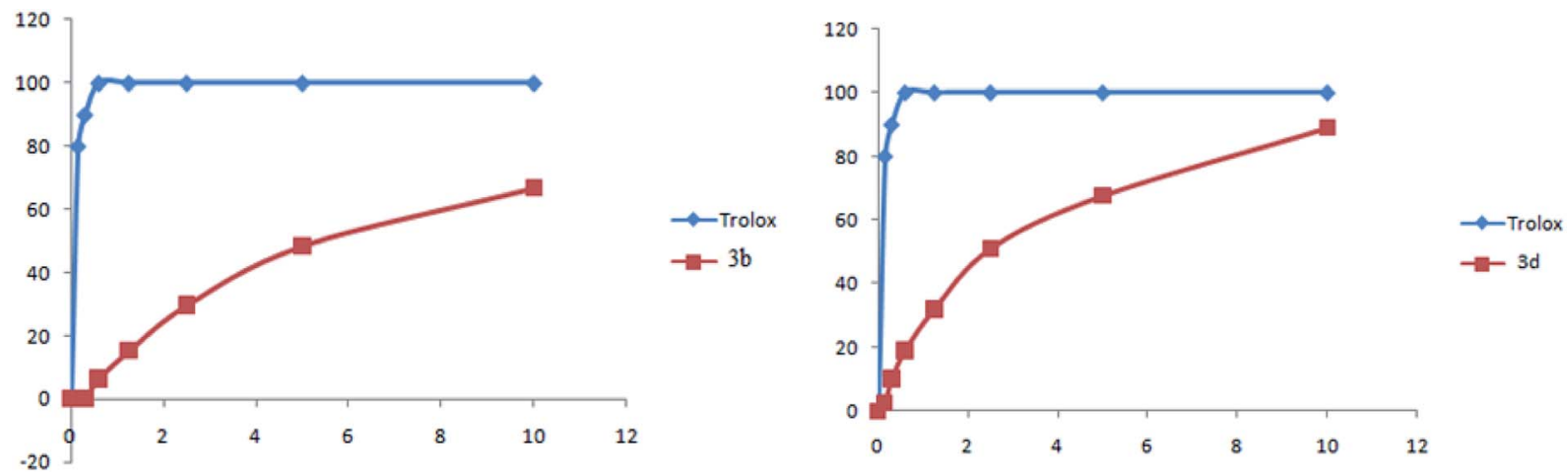

Fig. 8 Percent inhibition of complexes $3 b$ and $3 d$ as a function of concentration.

used as controls. The relative cell viability was calculated using the following formula:

Relative cell viability $(\%)=\mathrm{OD}$ treated C/OD control $\times 100 \%$

3.5.2. Disc diffusion method. Escherichia coli (ATCC10418), and methicillin-resistant Staphylococcus aureus (MRSA) (ATCC3359) were grown on nutrient agar plates (HiMedia, India) and Candida albicans (ATCC 90028) was grown on potato dextrose agar (HiMedia, India) for $24 \mathrm{~h}$ at $35{ }^{\circ} \mathrm{C}$. All cultures were obtained from the American Type Culture Collection (ATCC). The disc diffusion method was used to assess the antimicrobial activities (De Beer and Sherwood, 1945). ${ }^{42}$ Microbes were suspended in sterile saline solution $(0.9 \%)$ and the turbidity was adjusted to 0.5 OD value using spectrophotometer (Labomed Inc., USA). The inoculum was swabbed on the surface of agar plates used using a sterilized cotton swab. Sterile blank disks $(6 \mathrm{~mm})$ were loaded with $10 \mu \mathrm{l}$ of compounds stock solution $\left(10 \mathrm{mg} \mathrm{ml}^{-1}\right)$ giving a concentration of $50 \mu \mathrm{g}$ per disc. Commercial tetracycline discs ( $30 \mu \mathrm{g}$ per disc) were used as

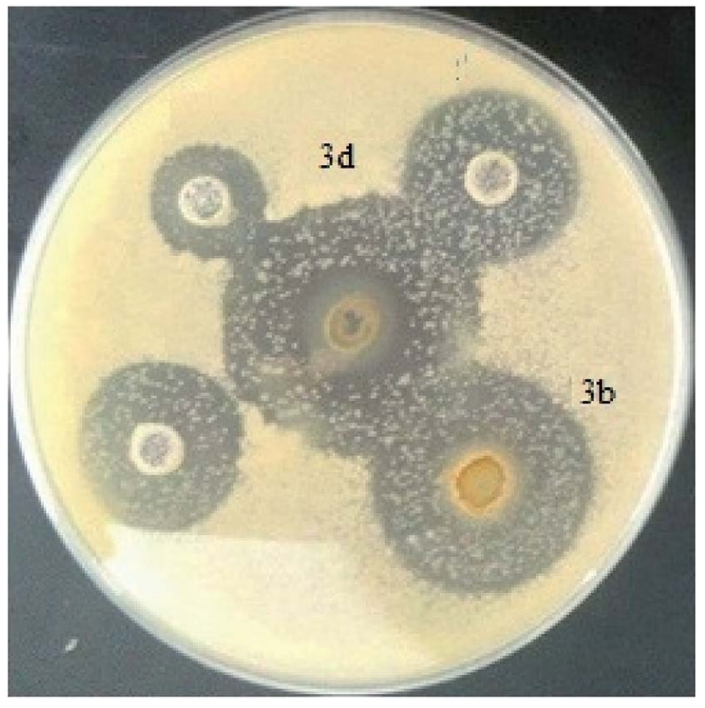

Fig. 9 Antifungal activity against Candida albicans.
Table 4 Minimum Inhibitory Concentrations (MICs) expressed in mg $\mathrm{ml}^{-1}$

\begin{tabular}{llllllll}
\hline \multirow{2}{*}{ Strain } & \multicolumn{2}{l}{ Compounds } \\
\cline { 2 - 7 } & 3a & $\mathbf{3 b}$ & $\mathbf{3 c}$ & $\mathbf{3 d}$ & $\mathbf{3 e}$ & $\mathbf{3 f}$ \\
\hline Candida albicans & - & $22 \pm 0.5$ & - & $34 \pm 0.18$ & - & - \\
\hline
\end{tabular}

Table 5 Acetylcholinesterase inhibitory activity (AChEI) (\%) of compounds $(3 a-f)$

\begin{tabular}{lllllll}
\hline Compounds & 3a & 3b & 3c & 3d & 3e & 3f \\
\hline (AChEI) (\%) & 32.8 & 45.3 & - & 47.1 & 38 & -
\end{tabular}

positive controls and methanol as a negative control for comparison. The Petri-plates were incubated at $35{ }^{\circ} \mathrm{C}$ for 24 hours. The diameters of the zones of inhibition produced by the compounds on the test isolates were measured in $\mathrm{mm}$.

The compounds were screened calorimetrically using 3-(4,5dimethylthiazol-2-yl)-2,5-diphenyltetrazolium bromide (MTT) cell assay in two human cancer cell lines namely MCF7 and MDA-MB-231 to evaluate their cytotoxicity. As shown in Table 6, many of the compounds affected cell viability of cancer cell lines and showed promising level of cytotoxicity however, the cytotoxicity of $3 \mathbf{e}$ and $\mathbf{3 d}$ was much stronger in MCF7 with $\mathrm{IC}_{50}$ values 0.68 and $0.6 \mu \mathrm{g} \mathrm{ml}^{-1}$, respectively as compared to their activity on MDA-MB-231 cells. The cytotoxicity of $\mathbf{3 e}$ and $\mathbf{3 d}$ on MDA-MB-231 cells was 1.93 and $3.1 \mu \mathrm{g} \mathrm{ml}^{-1}$. The cytotoxicity of compounds 3c in MCF7 and MDA-MB-231 cells was 1.7 and 16 $\mu \mathrm{g} \mathrm{ml}{ }^{-1}$, while the $\mathrm{IC}_{50}$ values of compound on $3 \mathbf{f}$ were 1.3 and $3.3 \mu \mathrm{g} \mathrm{ml}{ }^{-1}$ against MCF7 and MDA-MB-231, respectively.

The antimicrobial activities of the synthesized compounds against the human pathogenic microorganisms are presented in Table 6. The results revealed that the highest antimicrobial activity was reported in $\mathbf{3 e}$ (against $E$. coli) followed $\mathbf{3 d}$ (against E. coli) and $\mathbf{3 b}$ (against MRSA) however the highest anti Candida albicans activity was found in $3 \mathbf{d}(30.5 \mathrm{~mm})$ followed by $3 \mathbf{b}(28.0$ $\mathrm{mm})$ and $3 \mathbf{a}(25.0 \mathrm{~mm})$. Compound $3 \mathbf{c}$ was completely inactive against the three strains (Table 6). 
Table 6 Anticancer and antimicrobial profile of synthesized Ru-NHC complexes (3a-f)

\begin{tabular}{|c|c|c|c|c|c|}
\hline \multirow[b]{2}{*}{ Compounds } & \multicolumn{2}{|c|}{ Anticancer activity $\mathrm{IC}_{50}$ in $\mu \mathrm{g} \mathrm{ml}^{-1}$} & \multicolumn{3}{|c|}{ Antimicrobial activity (50 $\mu \mathrm{g}$ per disc) } \\
\hline & MCF7 & MDA-MB-231 & E. coli & $M R S A$ & C. albicans \\
\hline $3 \mathbf{b}$ & $3.1 \pm 3.1$ & $2.6 \pm 5.9$ & $23.3 \pm 1.5$ & $25.5 \pm 1.5$ & $28.5 \pm 1.5$ \\
\hline $3 c$ & $1.7 \pm 3.1$ & $16 \pm 2.8$ & $0.0 \pm 0.0$ & $0.0 \pm 0.0$ & $0.0 \pm 0.0$ \\
\hline 3d & $0.6 \pm 1.8$ & $3.1 \pm 00$ & $25.0 \pm 00$ & $25.5 \pm 0.5$ & $30.5 \pm 0.5$ \\
\hline Tetracycline & NT & NT & $22 \pm 0.3$ & 25.5 & $0.0 \pm 00$ \\
\hline
\end{tabular}

\section{Conclusion}

In summary, a new series of ruthenium-NHC complexes (3a-f) have been synthesized from silver-NHC complexes with $\left[\mathrm{RuCl}_{2}(p \text {-cymene })\right]_{2}$. All these compounds were characterized by spectroscopic and analytic techniques. To demonstrate the efficiency of 3a-c as catalyst precursors, transfer hydrogenations of ketones were performed. Excellent activity and good catalyst stability were observed under mild reaction conditions. Structural differences in $\mathbf{3 a - c}$ did not affect yields significantly. The Ru-NHC catalysts described here gave one of the highest conversion rates to date for transfer hydrogenation reaction catalyzed by Ru-NHC complexes with low base loading.

The complexes 3a-f were tested for their antibacterial activity against Micrococcus luteus LB 14110, Staphylococcus aureus ATCC 6538, Listeria monocytogenes ATCC 19117, Salmonella typhimurium ATCC 14028, Pseudomonas aeruginosa ATCC 49189 and E. coli. Obtained results show that the complexes $3 \mathbf{d}$ and $3 \mathbf{e}$ have an effective antibacterial activity against the used indicator bacteria. With regard to the scavenging activity of the synthesized complexes on the DPPH radical, we noted that compounds $\mathbf{3 b}$ and $\mathbf{3 d}$, from a concentration of $1 \mathrm{mg} \mathrm{ml} \mathrm{m}^{-1}$, present a very similar scavenging activity to that of the two used controls butylated hydroxytoluene (BHT) and gallic acid (GA). Interestingly, from a concentration of $10 \mathrm{mg} \mathrm{ml}^{-1}, \mathbf{3 b}$ and $\mathbf{3 d}$ complexes exhibited the percentage inhibition in order to $70 \%$ and $90 \%$ respectively. Concerning acetylcholinesterase inhibition activity (AChEI), according to our findings, compound 3d presents an interesting AChEI activity with $47.1 \%$ of inhibition. In addition, this complex presents against Candida albicans the highest diameter of growth inhibition zone with a value of the order of $34 \pm 0.18 \mathrm{~mm}$. The cytotoxic activity of the complexes (3a-f) was also determined against a panel of cell lines such us MDA-MB-231 and T47D. The most actives compounds are 3d and $3 \mathbf{e}$.

\section{Experimental section}

\subsection{Materials and methods}

All procedures were carried out under an inert atmosphere using standard Schlenk line techniques. Chemicals and solvents were purchased from Sigma Aldrich. The solvents used were purified and dried by MBraun SPS 800 solvent purification system. Column chromatography was performed by using silica gel 60 (70-230 mesh). ${ }^{1} \mathrm{H}$ NMR and ${ }^{13} \mathrm{C}$ NMR spectra were recorded at $300 \mathrm{MHz}\left({ }^{1} \mathrm{H}\right), 75 \mathrm{MHz}\left({ }^{13} \mathrm{C}\right)$ in $\mathrm{CDCl}_{3}$ with tetramethylsilane as an internal reference. The NMR studies were carried out in highquality $5 \mathrm{~mm}$ NMR tubes. Signals are quoted in parts per million as $\delta$ downfield from tetramethylsilane $(\delta=0.00)$ as an internal standard. NMR multiplicities are abbreviated as follows: $\mathrm{s}=$ singlet, $\mathrm{d}=$ doublet, $\mathrm{t}=$ triplet, $\mathrm{m}=$ multiplet. $\mathrm{GC}$ analyses of reactions mixtures have been done using a Shimadzu GC 2010Plus GCFID system. Column: Teknokroma TRB-5 capillary column, $30 \mathrm{~m} \times 0.32 \mathrm{~mm} \times 0.25 \mu \mathrm{m}$. Initial temperature at $50{ }^{\circ} \mathrm{C}$, held for $1 \mathrm{~min}$, ramp $2{ }^{\circ} \mathrm{C} \min ^{-1}$ next $90{ }^{\circ} \mathrm{C}$, held for $3 \mathrm{~min}$, ramp $40{ }^{\circ} \mathrm{C} \min ^{-1}$ next $240{ }^{\circ} \mathrm{C}$ held for $10 \mathrm{~min}$. The temperature of the injector and detector were held at $240{ }^{\circ} \mathrm{C}$. Melting points were determined with Kofler bench at Isste of Borj Cedria (Hammam Lif, University of Carthage, Borj Cedria, Tunisia).

\subsection{General procedure for preparation of the ruthenium- NHC complexes (3a-f)}

The ruthenium-NHC complexes were synthesized through transmetalation via silver-NHC complexes (2a-f). We reacted one equivalent of silver-NHC complexes and 0.5 equivalent of $\left[\mathrm{RuCl}_{2}(p \text {-cymene })\right]_{2}$ in anhydrous dichloromethane $(30 \mathrm{ml})$. The reaction mixture was stirred for 4 days at room temperature in the dark. Then the solution was filtered through Celite and the filtrate was concentrated to dryness in vacuum. The red solid obtained recrystallized from DCM-diethyl ether or DCMpentane. The structure of Ru-NHC complexes were determined by IR and NMR analysis.

\subsection{Dichloro-[1,3-bis(3,5-dimethylbenzyl)-benzimidazole-2- ylidene $](p$-cymene)ruthenium(II), 3a}

Yield: (85\%); $\operatorname{mp} 236{ }^{\circ} \mathrm{C} . \mathrm{C}_{37} \mathrm{H}_{45} \mathrm{Cl}_{2} \mathrm{~N}_{2} \mathrm{Ru}, M=689.75 \mathrm{~g} \mathrm{~mol}^{-1}$. IR: $\nu=1406\left(\nu_{\mathrm{C}-\mathrm{N}}\right) \mathrm{cm}^{-1} \cdot{ }^{1} \mathrm{H}$ NMR $\left(300 \mathrm{MHz}, \mathrm{CDCl}_{3}, \delta(\mathrm{ppm})\right)$ : $6.91\left(\mathrm{~s}, 2 \mathrm{H}, \mathrm{CH}_{2} \mathrm{C}_{6} \mathrm{H}_{3}\left(\mathrm{CH}_{3}\right)_{2}-3,5\right) ; 6.83\left(\mathrm{~s}, 2 \mathrm{H}, \mathrm{C}_{6} \mathrm{H}_{2}\left(\mathrm{CH}_{3}\right)_{2}-5,6\right)$; $6.68\left(\mathrm{~s}, 4 \mathrm{H}, \mathrm{CH}_{2} \mathrm{C}_{6} \mathrm{H}_{3}\left(\mathrm{CH}_{3}\right)_{2}-3,5\right) ; 6.59\left(\mathrm{~d}, 2 \mathrm{H}, p-\mathrm{CH}_{3} \mathrm{C}_{6} \mathrm{H}_{4}-\right.$ $\left.\mathrm{CH}\left(\mathrm{CH}_{3}\right)_{2}\right) ; 5.54$ (d, 2H, $\left.p-\mathrm{CH}_{3} \mathrm{C}_{6} \mathrm{H}_{4} \mathrm{CH}\left(\mathrm{CH}_{3}\right)_{2}\right) ; 5.29$ (d, $2 \mathrm{H}, \mathrm{H}_{1^{\prime}}$, $\mathrm{CH}_{2}$ ); 5.05 (d, 2H, $\left.\mathrm{H}_{1^{\prime \prime}}, \mathrm{CH}_{2}\right) ; 2.62\left(\mathrm{~m}, 1 \mathrm{H}, \mathrm{H}_{7^{\prime \prime \prime}}, p-\mathrm{CH}_{3} \mathrm{C}_{6} \mathrm{H}_{4^{-}}\right.$ $\left.\mathrm{CH}\left(\mathrm{CH}_{3}\right)_{2}\right) ; 2.30\left(\mathrm{~s}, 12 \mathrm{H}, \mathrm{H}_{\mathrm{c}, \mathrm{d}, \mathrm{e}, \mathrm{f}}, 4 \times \mathrm{CH}_{3}\right) ; 2.21\left(\mathrm{~s}, 6 \mathrm{H}, \mathrm{H}_{\mathrm{a}, \mathrm{b}}, 2 \times\right.$ $\left.\mathrm{CH}_{3}\right) ; 1.80\left(\mathrm{~s}, 3 \mathrm{H}, \mathrm{H}_{\mathrm{g}}, \mathrm{CH}_{3}\right) ; 1.14\left(\mathrm{~s}, 6 \mathrm{H}, \mathrm{H}_{\mathrm{h}, \mathrm{i}}, 2 \times \mathrm{CH}_{3}\right)\left(p-\mathrm{CH}_{3}-\right.$ $\left.\mathrm{C}_{6} \mathrm{H}_{4} \mathrm{CH}\left(\mathrm{CH}_{3}\right)_{2}\right) .{ }^{13} \mathrm{C} \mathrm{NMR}\left(\mathrm{CDCl}_{3}, 75 \mathrm{MHz}\right)(\delta(\mathrm{ppm})): 188.8\left(\mathrm{C}_{2}\right.$, 
NCN); 138.4; 138.2; 134.4; 132.3; 128.9; 123.5; 111.8; 107.3; 96.6; 84.9; $52.3\left(\mathrm{C}_{1^{\prime}, 1^{\prime \prime}}, 2 \times \mathrm{CH}_{2}\right) ; 30.6\left(\mathrm{C}_{7^{\prime \prime \prime}}, p-\mathrm{CH}_{3} \mathrm{C}_{6} \mathrm{H}_{4} \mathrm{CH}\left(\mathrm{CH}_{3}\right)_{2}\right) ; 22.6$ $\left(\mathrm{C}_{\mathrm{a}, \mathrm{b}}, 2 \times \mathrm{CH}_{3}, \mathrm{C}_{6} \mathrm{H}_{2}\left(\mathrm{CH}_{3}\right)_{2}-5,6\right) ; 21.6\left(\mathrm{C}_{\mathrm{c}, \mathrm{d}, \mathrm{e}, \mathrm{f}}, 4 \times \mathrm{CH}_{3}\right) ; 20.3$ $\left(\mathrm{C}_{\mathrm{h}, \mathrm{i}}, 2 \times \mathrm{CH}_{3}\right) ; 18.0\left(\mathrm{C}_{\mathrm{g}}, \mathrm{CH}_{3}\right)$.

DART-TOF-MS: $m / z=279,343$.

\subsection{Dichloro-[1,3-bis(4-methylbenzyl)benzimidazol-2- ylidene](p-cymene)-ruthenium(II), $3 \mathbf{b}$}

Yield: (90\%); mp $210{ }^{\circ} \mathrm{C} . \mathrm{C}_{35} \mathrm{H}_{41} \mathrm{Cl}_{2} \mathrm{~N}_{2} \mathrm{Ru}, M=733.85 \mathrm{~g} \mathrm{~mol}{ }^{-1}$. IR: $\nu=1409\left(\nu_{\mathrm{C}-\mathrm{N}}\right) \mathrm{cm}^{-1} \cdot{ }^{1} \mathrm{H}$ NMR $\left(300 \mathrm{MHz}, \mathrm{CDCl}_{3}, \delta(\mathrm{ppm})\right)$ : 0.14 (d, 4H, $\left.\mathrm{CH}_{2} \mathrm{C}_{6} \mathrm{H}_{4}\left(\mathrm{CH}_{3}\right)-4\right) ; 7.00$ (d, $\left.4 \mathrm{H}, \mathrm{CH}_{2} \mathrm{C}_{6} \mathrm{H}_{4}\left(\mathrm{CH}_{3}\right)-4\right)$; 6.79 (s, 2H, $\left.\mathrm{C}_{6} \mathrm{H}_{2}\left(\mathrm{CH}_{3}\right)_{2}-5,6\right) ; 6.46$ (d, $\left.2 \mathrm{H}, p-\mathrm{CH}_{3} \mathrm{C}_{6} \mathrm{H}_{4} \mathrm{CH}\left(\mathrm{CH}_{3}\right)_{2}\right)$; $5.68\left(\mathrm{~d}, 2 \mathrm{H}, p-\mathrm{CH}_{3} \mathrm{C}_{6} \mathrm{H}_{4} \mathrm{CH}\left(\mathrm{CH}_{3}\right)_{2}\right) ; 5.29\left(\mathrm{~s}, 2 \mathrm{H}, \mathrm{H}_{1^{\prime}}, \mathrm{CH}_{2}\right) ; 5.03$ (s, $\left.2 \mathrm{H}, \mathrm{H}_{1^{\prime \prime}}, \mathrm{CH}_{2}\right) ; 2.68$ (p, $\left.1 \mathrm{H}, \mathrm{H}_{7^{\prime \prime \prime}}, p-\mathrm{CH}_{3} \mathrm{C}_{6} \mathrm{H}_{4} \mathrm{CH}\left(\mathrm{CH}_{3}\right)_{2}\right) ; 2.34$ (s, $\left.6 \mathrm{H}, \mathrm{H}_{\mathrm{c}, \mathrm{d}}, 2 \times \mathrm{CH}_{3}\right) ; 2.18\left(\mathrm{~s}, 6 \mathrm{H}, \mathrm{H}_{\mathrm{a}, \mathrm{b}}, 2 \times \mathrm{CH}_{3}\right) ; 1.84\left(\mathrm{~s}, 3 \mathrm{H}, \mathrm{H}_{\mathrm{e}}\right.$, $\left.\mathrm{CH}_{3}\right) ; 1.16\left(\mathrm{~d}, 6 \mathrm{H}, \mathrm{H}_{\mathrm{f}, \mathrm{g}}, 2 \times \mathrm{CH}_{3}\right)\left(p-\mathrm{CH}_{3} \mathrm{C}_{6} \mathrm{H}_{4} \mathrm{CH}\left(\mathrm{CH}_{3}\right)_{2}\right) .{ }^{13} \mathrm{C}$ $\mathrm{NMR}\left(\mathrm{CDCl}_{3}, 75 \mathrm{MHz}\right)(\delta(\mathrm{ppm})): 189.0\left(\mathrm{C}_{2}, \mathrm{NCN}\right) ; 137.0 ; 134.9$; $134.4 ; 132.3 ; 129.6 ; 125.9 ; 111.9 ; 107.6 ; 97.0 ; 85.30 ; 52.5\left(\mathrm{C}_{1^{\prime}, 1^{\prime \prime}}, 2\right.$ $\left.\times \mathrm{CH}_{2}\right) ; 30.6\left(\mathrm{C}_{7^{\prime \prime \prime}}, p-\mathrm{CH}_{3} \mathrm{C}_{6} \mathrm{H}_{4} \mathrm{CH}\left(\mathrm{CH}_{3}\right)_{2}\right) ; 22.6\left(\mathrm{C}_{\mathrm{f}, \mathrm{g}}, 2 \times \mathrm{CH}_{3}\right)$; $21.2\left(\mathrm{C}_{\mathrm{c}, \mathrm{d}}, 2 \times \mathrm{CH}_{3}\right) ; 20.3\left(\mathrm{C}_{\mathrm{e}}, \mathrm{CH}_{3}\right) ; 18.3\left(\mathrm{C}_{\mathrm{a}, \mathrm{b}}, 2 \times \mathrm{CH}_{3}\right) ; 14.2$ $\left(\mathrm{C}_{\mathrm{h}}, \mathrm{CH}_{3}\right)$.

\subsection{Dichloro-[1,3-bis(4-tertbutylbenzyl)benzimidazol-2- ylidene](p-cymene)-ruthenium(II), 3c}

Yield: (87\%); $\operatorname{mp} 224{ }^{\circ} \mathrm{C} . \mathrm{C}_{40} \mathrm{H}_{53} \mathrm{Cl}_{2} \mathrm{~N}_{2} \mathrm{Ru}, M=733.85 \mathrm{~g} \mathrm{~mol}^{-1}$. IR: $\nu=1609\left(\nu_{\mathrm{C}-\mathrm{N}}\right) \mathrm{cm}^{-1} \cdot{ }^{1} \mathrm{H}$ NMR $\left(300 \mathrm{MHz}, \mathrm{CDCl}_{3}, \delta(\mathrm{ppm})\right)$ : 7.36 (d, $\left.4 \mathrm{H}, \mathrm{CH}_{2} \mathrm{C}_{6} \mathrm{H}_{4} \mathrm{C}\left(\mathrm{CH}_{3}\right)_{3}-4\right) ; 7.03$ (d, $4 \mathrm{H}, \mathrm{CH}_{2} \mathrm{C}_{6} \mathrm{H}_{4} \mathrm{C}\left(\mathrm{CH}_{3}\right)_{3}{ }^{-}$ 4); $6.82\left(\mathrm{~s}, 2 \mathrm{H}, \mathrm{C}_{6} \mathrm{H}_{2}\left(\mathrm{CH}_{3}\right)_{2}-5,6\right) ; 6.55\left(\mathrm{~d}, 2 \mathrm{H}, p \mathrm{CH}_{3} \mathrm{C}_{6} \mathrm{H}_{4^{-}}\right.$ $\left.\mathrm{CH}\left(\mathrm{CH}_{3}\right)_{2}\right) ; 5.62$ (d, $\left.2 \mathrm{H}, p-\mathrm{CH}_{3} \mathrm{C}_{6} \mathrm{H}_{4} \mathrm{CH}\left(\mathrm{CH}_{3}\right)_{2}\right) ; 5.31\left(\mathrm{~s}, 2 \mathrm{H}, \mathrm{H}_{1^{\prime}}\right.$, $\left.\mathrm{CH}_{2}\right) ; 5.02\left(\mathrm{~s}, 2 \mathrm{H}, \mathrm{H}_{1^{\prime \prime}}, \mathrm{CH}_{2}\right) ; 2.61\left(\mathrm{~s}, 6 \mathrm{H}, \mathrm{H}_{\mathrm{d}, \mathrm{g}}, 2 \times \mathrm{CH}_{3}\right) ; 2.19(\mathrm{~s}$, $\left.6 \mathrm{H}, \mathrm{H}_{\mathrm{a}, \mathrm{b}}, 2 \times \mathrm{CH}_{3}\right) ; 1.81\left(\mathrm{~s}, 3 \mathrm{H}, \mathrm{H}_{\mathrm{i}}, \mathrm{CH}_{3}\right) ; 1.66\left(\mathrm{~s}, 1 \mathrm{H}, \mathrm{H}_{7^{\prime \prime \prime}}, p\right.$ $\left.\mathrm{CH}_{3} \mathrm{C}_{6} \mathrm{H}_{4} \mathrm{CH}\left(\mathrm{CH}_{3}\right)_{2}\right) ; 1.31\left(\mathrm{~s}, 15 \mathrm{H}, \mathrm{H}_{\mathrm{c}, \mathrm{e}, \mathrm{f}, \mathrm{h}, \mathrm{l}}, 5 \times \mathrm{CH}_{3}\right) ; 1.12(\mathrm{~d}, 6 \mathrm{H}$, $\left.\mathrm{H}_{\mathrm{j}, \mathrm{k}}, 2 \times \mathrm{CH}_{3}\right)\left(p-\mathrm{CH}_{3} \mathrm{C}_{6} \mathrm{H}_{4} \mathrm{CH}\left(\mathrm{CH}_{3}\right)_{2}\right) .{ }^{13} \mathrm{C} \mathrm{NMR}\left(\mathrm{CDCl}_{3}, 75 \mathrm{MHz}\right)$ $(\delta(\mathrm{ppm})): 188.9\left(\mathrm{C}_{2}, \mathrm{NCN}\right) ; 150.4 ; 134.9 ; 134.4 ; 132.3 ; 125.8$; 125.5; 111.9; 106.8; 97.3; 85.5; $52.3\left(\mathrm{C}_{1^{\prime}, 1^{\prime \prime}}, 2 \times \mathrm{CH}_{2}\right) ; 41.1\left(\mathrm{C}_{7^{\prime \prime \prime}}, p\right.$ $\left.\mathrm{CH}_{3} \mathrm{C}_{6} \mathrm{H}_{4} \mathrm{CH}\left(\mathrm{CH}_{3}\right)_{2}\right) ; 34.6\left(\mathrm{C}_{\mathrm{d}, \mathrm{g}}, 2 \times \mathrm{CH}_{3}, \mathrm{CH}_{2} \mathrm{C}_{6} \mathrm{H}_{4} \mathrm{C}\left(\mathrm{CH}_{3}\right)_{3}-4\right)$; $31.4\left(\mathrm{C}_{\mathrm{c}, \mathrm{e}, \mathrm{f}, \mathrm{h}}, 4 \times \mathrm{CH}_{3}\right) ; 30.5\left(\mathrm{C}_{\mathrm{i}}, \mathrm{CH}_{3}\right) ; 22.6\left(\mathrm{C}_{\mathrm{a}, \mathrm{b}}, 2 \times \mathrm{CH}_{3}\right) ; 20.3$ $\left(\mathrm{C}_{\mathrm{j}, \mathrm{k}}, 2 \times \mathrm{CH}_{3}\right)$. DART-TOF-MS: $m / z=453,426,291$.

\subsection{Dichloro-[1-(3,5-dimethylbenzyl)-3-(2,3,5,6- tetramethylbenzyl)benzimidazol-2-ylidene $](p$-cymene $)$ ruthenium(II), 3d}

Yield: (88\%); mp $184{ }^{\circ} \mathrm{C} . \mathrm{C}_{39} \mathrm{H}_{49} \mathrm{Cl}_{2} \mathrm{~N}_{2} \mathrm{Ru}, M=0.717 .80 \mathrm{~g} \mathrm{~mol}^{-1}$. IR: $\nu=1418\left(\nu_{\mathrm{C}-\mathrm{N}}\right) \mathrm{cm}^{-1} .{ }^{1} \mathrm{H} \mathrm{NMR}\left(300 \mathrm{MHz}, \mathrm{CDCl}_{3}, \delta(\mathrm{ppm})\right)$ : $7.69\left(\mathrm{~d}, 2 \mathrm{H}, p-\mathrm{CH}_{3} \mathrm{C}_{6} \mathrm{H}_{4} \mathrm{CH}\left(\mathrm{CH}_{3}\right)_{2}\right) ; 7.54\left(\mathrm{~d}, 2 \mathrm{H}, p-\mathrm{CH}_{3} \mathrm{C}_{6} \mathrm{H}_{4}\right.$ $\left.\mathrm{CH}\left(\mathrm{CH}_{3}\right)_{2}\right) ; 7.26\left(\mathrm{~s}, 1 \mathrm{H}, \mathrm{CH}_{2} \mathrm{C}_{6} \mathrm{H}_{3}\left(\mathrm{CH}_{3}\right)_{2}-3,5\right) ; 6.89\left(\mathrm{~s}, 2 \mathrm{H}, \mathrm{CH}_{2}-\right.$ $\left.\mathrm{C}_{6} \mathrm{H}_{3}\left(\mathrm{CH}_{3}\right)_{2}-3,5\right) ; 6.63\left(\mathrm{~s}, 2 \mathrm{H}, \mathrm{C}_{6} \mathrm{H}_{2}\left(\mathrm{CH}_{3}\right)_{2}-5,6\right) ; 5.88(\mathrm{~s}, 1 \mathrm{H}$, $\left.\mathrm{CH}_{2} \mathrm{C}_{6} H\left(\mathrm{CH}_{3}\right)_{4}-2,3,5,6\right) ; 4.21\left(\mathrm{~s}, 4 \mathrm{H}, \mathrm{H}_{1^{\prime}, 1^{\prime \prime}}, 2 \times \mathrm{CH}_{2}\right) ; 2.86(\mathrm{p}, 1 \mathrm{H}$, $\left.\mathrm{H}_{7^{\prime \prime \prime}}, p-\mathrm{CH}_{3} \mathrm{C}_{6} \mathrm{H}_{4} \mathrm{CH}\left(\mathrm{CH}_{3}\right)_{2}\right) ; 2.27\left(\mathrm{~s}, 18 \mathrm{H}, \mathrm{H}_{\mathrm{a}, \mathrm{b}, \mathrm{c}, \mathrm{d}, \mathrm{f}, \mathrm{g}}, 6 \times \mathrm{CH}_{3}\right)$; $2.20\left(\mathrm{~s}, 3 \mathrm{H}, \mathrm{H}_{\mathrm{i}}, \mathrm{CH}_{3}\right) ; 1.95\left(\mathrm{~s}, 3 \mathrm{H}, \mathrm{H}_{\mathrm{l}}, \mathrm{CH}_{3}\right) ; 1.32\left(\mathrm{~s}, 6 \mathrm{H}, \mathrm{H}_{\mathrm{e}, \mathrm{h}}, 2 \times\right.$ $\left.\mathrm{CH}_{3}\right) ; 0.92\left(\mathrm{~s}, 6 \mathrm{H}, \mathrm{H}_{\mathrm{j}, \mathrm{k}}, 2 \times \mathrm{CH}_{3}\right)\left(p-\mathrm{CH}_{3} \mathrm{C}_{6} \mathrm{H}_{4} \mathrm{CH}\left(\mathrm{CH}_{3}\right)_{2}\right) \cdot{ }^{13} \mathrm{C}$ NMR $\left(\mathrm{CDCl}_{3}, 75 \mathrm{MHz}\right)(\delta(\mathrm{ppm})): 187.8\left(\mathrm{C}_{2}, \mathrm{NCN}\right) ; 138.4 ; 135.4$; $135.2 ; 134.5 ; 133.5 ; 133.2 ; 132.3 ; 131.6 ; 131.3 ; 130.0 ; 128.9$; 124.6; 123.4; 107.1; 96.2; $54.0\left(\mathrm{C}_{1^{\prime}}, \mathrm{CH}_{2}\right) ; 51.8\left(\mathrm{C}_{1^{\prime \prime}}, \mathrm{CH}_{2}\right) ; 31.0$ $\left(\mathrm{C}_{7^{\prime \prime \prime}}, \quad p-\mathrm{CH}_{3} \mathrm{C}_{6} \mathrm{H}_{4} \mathrm{CH}\left(\mathrm{CH}_{3}\right)_{2}\right) ; 21.5 \quad\left(\mathrm{C}_{\mathrm{j}, \mathrm{k}}, \quad 2 \times \mathrm{CH}_{3}, \quad p\right.$
$\left.\mathrm{CH}_{3} \mathrm{C}_{6} \mathrm{H}_{4} \mathrm{CH}\left(\mathrm{CH}_{3}\right)_{2}\right) ; 20.8\left(\mathrm{C}_{\mathrm{c}, \mathrm{d}}, 2 \times \mathrm{CH}_{3}\right) ; 20.2\left(\mathrm{C}_{\mathrm{i}}, \mathrm{CH}_{3}\right) ; 18.4$ $\left(\mathrm{C}_{\mathrm{f}, \mathrm{g}}, 2 \times \mathrm{CH}_{3}\right) ; 16.3\left(\mathrm{C}_{\mathrm{a}, \mathrm{b}}, 2 \times \mathrm{CH}_{3}\right) ; 15.4\left(\mathrm{C}_{\mathrm{e}, \mathrm{h}, \mathrm{l}}, 3 \times \mathrm{CH}_{3}\right)$.

\subsection{Dichloro-[1-(3,5-dimethylbenzyl)-3-(4-tertbutylbenzyl) benzimidazol-2-ylidene]( $p$-cymene) ruthenium(II), $3 \mathrm{e}$}

Yield: (86\%); $\operatorname{mp~} 222{ }^{\circ} \mathrm{C} . \mathrm{C}_{39} \mathrm{H}_{49} \mathrm{Cl}_{2} \mathrm{~N}_{2} \mathrm{Ru}, M=717.80 \mathrm{~g} \mathrm{~mol}^{-1}$. IR: $\nu=1404\left(\nu_{\mathrm{C}-\mathrm{N}}\right) \mathrm{cm}^{-1} \cdot{ }^{1} \mathrm{H}$ NMR $\left(300 \mathrm{MHz}, \mathrm{CDCl}_{3}, \delta(\mathrm{ppm})\right)$ : $7.34\left(\mathrm{~d}, 2 \mathrm{H}, p-\mathrm{CH}_{3} \mathrm{C}_{6} \mathrm{H}_{4} \mathrm{CH}\left(\mathrm{CH}_{3}\right)_{2}\right) ; 7.03\left(\mathrm{~d}, 2 \mathrm{H}, p-\mathrm{CH}_{3} \mathrm{C}_{6} \mathrm{H}_{4}\right.$ $\left.\mathrm{CH}\left(\mathrm{CH}_{3}\right)_{2}\right) ; 6.92\left(\mathrm{~s}, 1 \mathrm{H}, \mathrm{CH}_{2} \mathrm{C}_{6} \mathrm{H}_{3}\left(\mathrm{CH}_{3}\right)_{2}-3,5\right) ; 6.84$ (s, 4H, $\mathrm{CH}_{2}-$ $\left.\mathrm{C}_{6} \mathrm{H}_{4} \mathrm{C}\left(\mathrm{CH}_{3}\right)_{3}-4\right) ; 6.68\left(\mathrm{~s}, 2 \mathrm{H}, \mathrm{CH}_{2} \mathrm{C}_{6} \mathrm{H}_{4} C\left(\mathrm{CH}_{3}\right)_{3}-4\right) ; 6.54(\mathrm{~s}, 2 \mathrm{H}$, $\left.\mathrm{CH}_{2} \mathrm{C}_{6} \mathrm{H}_{3}\left(\mathrm{CH}_{3}\right)_{2}-3,5\right) ; 5.58\left(\mathrm{~s}, 2 \mathrm{H}, \mathrm{C}_{6} \mathrm{H}_{2}\left(\mathrm{CH}_{3}\right)_{2}-5,6\right) ; 5.30(\mathrm{~s}, 2 \mathrm{H}$, $\left.\mathrm{H}_{1^{\prime}}, \mathrm{CH}_{2}\right) ; 5.01$ (s, 2H, $\left.\mathrm{H}_{1^{\prime \prime}}, \mathrm{CH}_{2}\right) ; 2.58\left(\mathrm{p}, 1 \mathrm{H}, \mathrm{H}_{7^{\prime \prime \prime}}, p-\mathrm{CH}_{3} \mathrm{C}_{6} \mathrm{H}_{4^{-}}\right.$ $\left.\mathrm{CH}\left(\mathrm{CH}_{3}\right)_{2}\right) ; 2.30\left(\mathrm{~s}, 6 \mathrm{H}, \mathrm{H}_{\mathrm{c}, \mathrm{d}}, 2 \times \mathrm{CH}_{3}\right) ; 2.20\left(\mathrm{~s}, 6 \mathrm{H}, \mathrm{H}_{\mathrm{a}, \mathrm{b}}, 2 \times\right.$ $\left.\mathrm{CH}_{3}\right) ; 1.81\left(\mathrm{~s}, 3 \mathrm{H}, \mathrm{H}_{\mathrm{f}}, \mathrm{CH}_{3}\right) ; 1.57\left(\mathrm{~s}, 3 \mathrm{H}, \mathrm{H}_{\mathrm{h}}, \mathrm{CH}_{3}\right) ; 1.31(\mathrm{~s}, 6 \mathrm{H}$, $\left.\mathrm{H}_{\mathrm{i}, \mathrm{j}}, 2 \times \mathrm{CH}_{3}\right)\left(p-\mathrm{CH}_{3} \mathrm{C}_{6} \mathrm{H}_{4} \mathrm{CH}\left(\mathrm{CH}_{3}\right)_{2}\right) ; 1.12\left(\mathrm{~s}, 6 \mathrm{H}, \mathrm{H}_{\mathrm{e}, \mathrm{g}}, 2 \times\right.$ $\left.\mathrm{CH}_{3}\right) .{ }^{13} \mathrm{C} \mathrm{NMR}\left(\mathrm{CDCl}_{3}, 75 \mathrm{MHz}\right)(\delta(\mathrm{ppm})): 189.1\left(\mathrm{C}_{2}, \mathrm{NCN}\right)$; $150.4 ; 138.4 ; 138.2 ; 135.0 ; 134.4 ; 132.3 ; 129.0 ; 127.7 ; 125.7$; 125.6; 123.6; 111.9; 107.1; 97.0; 85.2; $52.3\left(\mathrm{C}_{1^{\prime}}, \mathrm{CH}_{2}\right) ; 52.2\left(\mathrm{C}_{1^{\prime \prime}}\right.$, $\left.\mathrm{CH}_{2}\right)$; $34.6\left(\mathrm{C}_{7^{\prime \prime \prime}}, p-\mathrm{CH}_{3} \mathrm{C}_{6} \mathrm{H}_{4} \mathrm{CH}\left(\mathrm{CH}_{3}\right)_{2}\right) ; 31.4\left(\mathrm{C}_{\mathrm{c}, \mathrm{d}}, 2 \times \mathrm{CH}_{3}, p\right.$ $\left.\mathrm{CH}_{3} \mathrm{C}_{6} \mathrm{H}_{4} \mathrm{CH}\left(\mathrm{CH}_{3}\right)_{2}\right) ; 30.5\left(\mathrm{C}_{\mathrm{a}, \mathrm{b}}, 2 \times \mathrm{CH}_{3}\right) ; 22.7\left(\mathrm{C}_{\mathrm{f}}, \mathrm{CH}_{3}\right) ; 21.6$ $\left(\mathrm{C}_{\mathrm{i}, \mathrm{j}}, 2 \times \mathrm{CH}_{3}\right) ; 20.3\left(\mathrm{C}_{\mathrm{h}}, \mathrm{CH}_{3}\right) ; 18.1\left(\mathrm{C}_{\mathrm{e}, \mathrm{g}}, 2 \times \mathrm{CH}_{3}\right)$.

\subsection{Dichloro-[1-(3,5-dimethylbenzyl)-3-(4-methylbenzyl) benzimidazol-2-ylidene $]$ ( $p$-cymene) ruthenium(II), $3 \mathrm{f}$}

Yield: (80\%); $\mathrm{mp} 204{ }^{\circ} \mathrm{C} . \mathrm{C}_{36} \mathrm{H}_{43} \mathrm{Cl}_{2} \mathrm{~N}_{2} \mathrm{Ru}, M=675.73 \mathrm{~g} \mathrm{~mol}^{-1}$. IR: $\nu=1404\left(\nu_{\mathrm{C}-\mathrm{N}}\right) \mathrm{cm}^{-1} \cdot{ }^{1} \mathrm{H}$ NMR $\left(300 \mathrm{MHz}, \mathrm{CDCl}_{3}, \delta(\mathrm{ppm})\right)$ : $7.13\left(\mathrm{~d}, 2 \mathrm{H}, p-\mathrm{CH}_{3} \mathrm{C}_{6} \mathrm{H}_{4} \mathrm{CH}\left(\mathrm{CH}_{3}\right)_{2}\right) ; 7.00\left(\mathrm{~d}, 2 \mathrm{H}, p-\mathrm{CH}_{3} \mathrm{C}_{6} \mathrm{H}_{4}\right.$ $\left.\mathrm{CH}\left(\mathrm{CH}_{3}\right)_{2}\right) ; 6.92\left(\mathrm{~s}, 1 \mathrm{H}, \mathrm{CH}_{2} \mathrm{C}_{6} \mathrm{H}_{3}\left(\mathrm{CH}_{3}\right)_{2}-3,5\right) ; 6.84$ (d, $4 \mathrm{H}, \mathrm{CH}_{2}-$ $\left.\mathrm{C}_{6} \mathrm{H}_{4}\left(\mathrm{CH}_{3}\right)-4\right) ; 6.67\left(\mathrm{~s}, 2 \mathrm{H}, \mathrm{CH}_{2} \mathrm{C}_{6} \mathrm{H}_{3}\left(\mathrm{CH}_{3}\right)_{2}-3,5\right) ; 6.51(\mathrm{~m}, 2 \mathrm{H}$, $\left.\mathrm{CH}_{2} \mathrm{C}_{6} \mathrm{H}_{4}\left(\mathrm{CH}_{3}\right)-4\right) ; 5.57\left(\mathrm{~m}, 2 \mathrm{H}, \mathrm{C}_{6} \mathrm{H}_{2}\left(\mathrm{CH}_{3}\right)_{2}-5,6\right) ; 5.30\left(\mathrm{~s}, 2 \mathrm{H}_{1} \mathrm{H}_{1^{\prime}}\right.$, $\left.\mathrm{CH}_{2}\right) ; 5.02\left(\mathrm{~s}, 2 \mathrm{H}, \mathrm{H}_{1^{\prime \prime}}, \mathrm{CH}_{2}\right) ; 2.64\left(\mathrm{p}, 1 \mathrm{H}, \mathrm{H}_{7^{\prime \prime \prime}} p-\mathrm{CH}_{3} \mathrm{C}_{6} \mathrm{H}_{4}-\right.$ $\left.\mathrm{CH}\left(\mathrm{CH}_{3}\right)_{2}\right) ; 2.34\left(\mathrm{~s}, 3 \mathrm{H}, \mathrm{H}_{\mathrm{e}}, \mathrm{CH}_{3}\right) ; 2.30\left(\mathrm{~s}, 6 \mathrm{H}, \mathrm{H}_{\mathrm{c}, \mathrm{d}}, 2 \times \mathrm{CH}_{3}\right) ; 2.19$ $\left(\mathrm{s}, 6 \mathrm{H}, \mathrm{H}_{\mathrm{a}, \mathrm{b}}, 2 \times \mathrm{CH}_{3}\right) ; 1.82\left(\mathrm{~s}, 3 \mathrm{H}, \mathrm{H}_{\mathrm{f}}, \mathrm{CH}_{3}\right) ; 1.58\left(\mathrm{~s}, 3 \mathrm{H}, \mathrm{H}_{\mathrm{i}}, \mathrm{CH}_{3}\right)$; $1.15\left(\mathrm{~s}, 6 \mathrm{H}, \mathrm{H}_{\mathrm{g}, \mathrm{h}}, 2 \times \mathrm{CH}_{3}\right)\left(p-\mathrm{CH}_{3} \mathrm{C}_{6} \mathrm{H}_{4} \mathrm{CH}\left(\mathrm{CH}_{3}\right)_{2}\right) .{ }^{13} \mathrm{C} \mathrm{NMR}$ $\left(\mathrm{CDCl}_{3}, 75 \mathrm{MHz}\right)(\delta(\mathrm{ppm})): 189.2\left(\mathrm{C}_{2}, \mathrm{NCN}\right) ; 138.4 ; 138.2 ; 137.0$; $135.0 ; 134.5 ; 134.3 ; 132.3 ; 129.6 ; 129.0 ; 125.8 ; 123.6 ; 111.9$; 107.4; 96.6; 85.2; $52.4\left(\mathrm{C}_{1^{\prime}}, \mathrm{CH}_{2}\right) ; 52.2\left(\mathrm{C}_{1^{\prime \prime}}, \mathrm{CH}_{2}\right) ; 30.6\left(\mathrm{C}_{7^{\prime \prime \prime}}, p\right.$ $\left.\mathrm{CH}_{3} \mathrm{C}_{6} \mathrm{H}_{4} \mathrm{CH}\left(\mathrm{CH}_{3}\right)_{2}\right) ; 21.6\left(\mathrm{C}_{\mathrm{h}, \mathrm{g}}, 2 \times \mathrm{CH}_{3}, p-\mathrm{CH}_{3} \mathrm{C}_{6} \mathrm{H}_{4} \mathrm{CH}\left(\mathrm{CH}_{3}\right)_{2}\right)$; $21.2\left(\mathrm{C}_{\mathrm{c}, \mathrm{d}}, 2 \times \mathrm{CH}_{3}\right) ; 22.3\left(\mathrm{C}_{\mathrm{e}, \mathrm{f}}, 2 \times \mathrm{CH}_{3}\right) ; 18.1\left(\mathrm{C}_{\mathrm{a}, \mathrm{b}, \mathrm{i}}, 3 \times \mathrm{CH}_{3}\right)$.

\subsection{Antibacterial activity}

5.9.1. Bacterial strains, media and growth conditions. Bacteria strains used as indicator microorganisms for the antibacterial activity assays were: Micrococcus luteus (M. luteus) LB 14110, Staphylococcus aureus (S. aureus) ATCC6538, Listeria monocytogenes (L. monocytogenes) ATCC 19117, Salmonella typhimurium (S. typhimurium) ATCC 14028, Pseudomonas aeruginosa ( $P$. aeruginosa) ATCC 49189 and E. coli were obtained from International Culture Collections (ATCC) and local culture collection of the Laboratory of Microorganisms and Biomolecules of the Centre of Biotechnology of Sfax-Tunisia.

These bacterial strains were grown overnight in Luria-Bertani (LB) agar medium ( $\left.\mathrm{g} \mathrm{l}^{-1}\right)$ : peptone 10; yeast extract 5 and $\mathrm{NaCl} 5$ at $\mathrm{pH} 7.2$ under aerobic conditions and constant agitation (200 rpm) at $30{ }^{\circ} \mathrm{C}$ for M. luteus LB14110 and L. monocytogenes ATCC 19117 and at $37^{\circ} \mathrm{C}$ for $S$. aureus ATCC 6538, S. 
typhimurium ATCC 14028 and P. aeruginosa ATCC49189, and then diluted $1: 100$ in LB media and incubated for $5 \mathrm{~h}$ under constant agitation $(200 \mathrm{rpm})$ at the appropriate temperature.

5.9.2. Agar well diffusion method. Agar well diffusion method was employed for the determination of the antimicrobials activity of the synthesized compounds according to Güven et al. (2006) with some modifications. Briefly, the synthesized compounds are allowed to diffuse out into the appropriate agar medium (LB agar medium) and interact in a plate freshly seeded with a suspension of the indicators microorganisms $\left(0.1 \mathrm{ml}\right.$ of $10^{8}$ cells per $\left.\mathrm{ml}\right)$. The plate was incubated at the appropriate temperature after staying at $4{ }^{\circ} \mathrm{C}$ for $2 \mathrm{~h}$. The resulting zones of inhibition will be uniformly circular as there will be a confluent lawn of growth. The antibacterial activity was assayed by measuring in millimeters the diameter of the inhibition zone formed around the well. All tests are assayed in triplicate and expressed as the average \pm standard deviation of the measurements.

5.9.3. Minimum inhibitory concentration (MIC). The minimum inhibitory concentration (MIC) of the synthesized compounds was determined in accordance with NCCLS guideline M7-A6 and M38-P (National Committee for clinical laboratory standard, Wayne 1998). The test was performed in sterile 96well microplates with a final volume in each microplate well of $100 \mu \mathrm{l}$. The synthesized compounds $\left(20 \mathrm{mg} \mathrm{ml}^{-1}\right)$ were properly prepared in solution of dimethylsulfoxide (DMSO)/water (1/9; v/ v). The inhibitory activity of each synthesized compound was transferred to each well in order to obtain a twofold serial dilution of the original sample and visible growth after incubation. As an indicator of microorganism growth, $25 \mu \mathrm{l}$ of Thiazolyl Blue Tetrazolium Bromide (MTT), indicator solution $\left(0.5 \mathrm{mg} \mathrm{ml}^{-1}\right.$ ) dissolved in sterile water were added to the wells and incubated at room temperature for $30 \mathrm{~min}$. This determination was done in triplicate and obtained results were very similar. The reported value is the average of the three tests.

5.9.4. Antioxidant activity: DPPH radical scavenging activity. Scavenging of 2,2-diphenyl-1-picrylhydrazyl radical (DPPH ${ }^{*}$ assay) is the simplest and most widely reported method for screening antioxidant activity. The procedure involves measurement of decrease in absorbance of DPPH at its absorption maxima of $517 \mathrm{~nm}$. This assay determines the scavenging of stable radical species according to the method of Kirby and Schmidt, (1997) with slight modifications. Briefly, synthesized compounds were dissolved in dimethylsulfoxide (DMSO)/water $(1 / 9 ; \mathrm{v} / \mathrm{v})$ and diluted with ultrapure water at different concentrations $(1,0.5,0.250,0.125,0.0625$, $\left.0.03125 \mathrm{mg} \mathrm{ml}^{-1}\right)$. Then, $500 \mu \mathrm{l}$ of a $4 \%(\mathrm{w} / \mathrm{v})$ solution of DPPH radical in ethanol was mixed with $500 \mu \mathrm{l}$ of samples. The mixture was incubated for $30 \mathrm{~min}$ in the dark at room temperature. The scavenging capacity was determined spectrophotometrically by monitoring the decrease in absorbance at $517 \mathrm{~nm}$ against a blank. The percentage of antiradical activity (\% ArA) had been calculated as follows:

$\% \operatorname{ArA}=[($ absorbance of control - absorbance of test sample $) /$ absorbance of control] $\times 100$.
All tests are assayed in triplicate and expressed as the average \pm standard deviation of the measurements to produce the concentration range of $0.0048-20 \mathrm{mg} \mathrm{ml}^{-1}$. To each test well 10 $\mu \mathrm{l}$ of cell suspension were added to final inoculum concentrations of $106 \mathrm{CFU} \mathrm{ml}^{-1}$ for each microorganisms. Positive growth control wells consisted of microorganisms only in their adequate medium. Cells suspension at the same concentration supplemented with ampicillin was used as control. The plates were then covered with the sterile plate covers and incubated at the appropriate temperature of each microorganism. The MIC was defined as the lowest concentration of the synthesized compound at which the microorganism does not demonstrate.

5.9.5. Antioxidant activity: ABTS radical scavenging activity. This manipulation was carried out according to the protocol proposed by Re et al. (1999) with some modifications, ${ }^{\mathbf{1 4}}$ $20 \mu \mathrm{l}$ of extract were mixed with $18 \mu \mathrm{l}$ of ABTS $^{{ }^{+}}$solution, the whole was mixed vigorously for $30 \mathrm{~s}$. A control consisting of ethanol and ultrapure water was prepared (5:5) v/v to which the previous solution was added. White is ethanol and ultrapure water $(5: 5) \mathrm{v} / \mathrm{v}$. Samples and control were incubated for $6 \mathrm{~min}$ in the dark, then the OD was measured at $734 \mathrm{~nm}$. Gallic acid, ascorbic acid and BHT were used as standards the calculation is done according to the following formula:

$$
\mathrm{AAO} x \%=\left[\left(A_{\mathrm{c}}-A_{\mathrm{e}}\right) / A_{\mathrm{c}}\right] \times 100
$$

$A_{\mathrm{c}}$ : absorbance of the control, $A_{\mathrm{e}}$ : absorbance of the sample.

\subsection{Antifungal activity}

5.10.1. Assessment, yeast strain and growth conditions. The choice of fungal strains is an important step in the antifungal screening study; it should be focused first on sensitive reference strains. This prompted us to carry out tests on multidrug-resistant yeast of Candida albicans.

Antifungal activity was evaluated against Candida albicans. This strain is a species of yeast. The evaluation of the activity of the compounds synthesized with respect to the strain of $C$. albicans was carried out using the diffusion method on a solid medium.

C. albicans is cultivated in a YPD medium whose composition is as follows: $10 \mathrm{~g}$ of yeast extract; $20 \mathrm{~g}$ peptone; $20 \mathrm{~g}$ glucose (or dextrose); $\mathrm{H}_{2} \mathrm{O}$ qsp $1 \mathrm{~L}$; $\mathrm{pH}=5.6$.

5.10.2. Agar well diffusion method. For the determination of the antifungal activity, the yeast has been cultivated:

In solid medium: C. albicans is cultivated in Sabouraud medium and incubated for $48 \mathrm{~h}$ at $30{ }^{\circ} \mathrm{C}$.

In liquid medium: $C$. albicans is cultivated in YPD medium in Erlenmeyer flasks. The cultures are incubated at $30{ }^{\circ} \mathrm{C}$ for $48 \mathrm{~h}$ with constant stirring at $250 \mathrm{rpm}$. For preservation, $200 \mu \mathrm{l}$ of each culture is mixed with $800 \mu$ of glycerol in cryotubes and stored at $-80{ }^{\circ} \mathrm{C}$.

5.10.3. Acetylcholinesterase inhibitory potential (AChEI). AChE inhibitory activity was measured by slightly modified spectrophotometric method of Ellman et al. (1961). Electric eel AChE was used, while acetylthiocholine iodide (ATCI) was employed as substrate of the reaction. 5,5'-Dithiobis-(2- 
nitrobenzoic acid) (DTNB) was used for the measurement of the antiacetylcholinesterase activity. Briefly, in this method, $100 \mu \mathrm{l}$ of Tris buffer at $50 \mathrm{mM}$ (pH 8.0), $30 \mu \mathrm{l}$ of sample or standard and $5 \mu \mathrm{l}$ of AChE enzyme $\left(0.5 \mathrm{U} \mathrm{ml}^{-1}\right)$ were added in a 96 well microplate and incubated for $10 \mathrm{~min}$ at $25{ }^{\circ} \mathrm{C}$. Then, $142 \mu \mathrm{l}$ of DTNB $(3 \mathrm{mM})$ and $23 \mu \mathrm{l}$ of substrate $(75 \mathrm{mM})$ were added. Hydrolysis of ATCI was monitored by the formation of the yellow 5-thio-2-nitrobenzoate anion as a result of the reaction of DTNB with thiocholines, catalyzed by enzymes at $405 \mathrm{~nm}$ utilizing a 96 well microplates reader (Thermo Scientific/ Varioskan Flash, Germany). The kinetic reaction has been followed until the AChE activity decreased, and then the reaction has been stopped. Percentage of inhibition of AChE was determined by comparison of rates reaction of samples relative to control (10\% DMSO in Tris buffer) using the following formula:

$$
\% \mathrm{AChEI}=1-\left(\delta A_{\text {sample }} / \delta A_{\text {control }}\right) \times 100
$$

where $\delta A_{\text {sample: }}$ sample absorbance at zero time - sample absorbance at the end of reaction, and $\delta A_{\text {control }}$ : control absorbance at zero time - control absorbance at the end of reaction. Galanthamine was used as standard.

All synthesised compounds have been tested at $100 \mu \mathrm{g} \mathrm{ml}$ of concentration. This determination was done in triplicate and obtained results were very similar. The reported value is the average of the three tests.

\section{Conflicts of interest}

There are no conflicts to declare.

\section{Acknowledgements}

This work was financed by the Research Supporting Project (RSP-2019/75), King Saud University, Riyadh Saudi Arabia.

\section{References}

1 T. Ikayira and A. J. Blacker, Acc. Chem. Res., 2007, 40, 1300.

2 G. Zassinovich, G. Mestroni and S. Gladiali, Chem. Rev., 1992, 92, 1051.

3 C. F. de Graauw, J. A. Peters, H. van Bekkum and J. Husken, Synthesis, 1994, 10, 1007.

4 R. Noyori and S. Hashigushi, Acc. Chem. Res., 1997, 30, 97.

5 M. Yamakawa, H. Ito and R. Noyori, J. Am. Chem. Soc., 2000, 122, 1466.

6 R. Noyori, Angew. Chem., Int. Ed., 2002, 41, 2008.

7 M. Bierenstiel, M. Dymarska, E. de Jong and M. Schlaf, J. Mol. Catal. A: Chem., 2008, 290, 1.

8 M. Zhao, Z. Yu, S. Yan and Y. Li, Tetrahedron Lett., 2009, 50, 4624.

9 M. Yigit, B. Yigit, I. Özdemir, E. Çetinkaya and B. Çetinkaya, Appl. Organomet. Chem., 2006, 20, 322.

10 (a) N. Marion, S. Diez-Gonzalez and S. P. Nolan, Angew. Chem., Int. Ed., 2007, 46, 2988; (b) D. Enders, O. Niemeier and A. Henseler, Chem. Rev., 2007, 107, 5606; (c) V. Nair,
S. Bindu and V. Sreekumar, Angew. Chem., Int. Ed., 2004, 43, 5130.

11 (a) S. P. Nolan, N-Heterocyclic Carbenes in Synthesis, WileyVCH Verlag GmbH \& Co. KGaA, Weinheim, 2006; (b) F. Glorius, N-Heterocyclic Carbenes in Transition Metal Catalysis Topics in Organometallic Chemistry, SpringerVerlag, Berlin, 2007; (c) W. A. Herrmann and C. Kocher, Angew. Chem., Int. Ed., 2007, 36, 2162; (d) W. A. Herrmann, M. Elison, J. Fischer, C. Kocher and G. R. J. Artus, Angew. Chem., Int. Ed. Engl., 1995, 34, 2371.

12 A. J. Arduengo, H. L. Harlow and M. Kline, J. Am. Chem. Soc., 1991, 113, 361.

13 (a) E. Peris and R. H. Crabtree, Coord. Chem. Rev., 2004, 248, 2239; (b) M. C. Perry and K. Burgess, Tetrahedron: Asymmetry, 2003, 14, 951.

14 A. J. Arduengo, R. L. Harlow and M. Kline, J. Am. Chem. Soc., 1991, 113, 361.

15 C. W. K. Gstottmayr, V. P. W. Bohm, E. Herdtweck, M. Grosche and W. A. Herrmann, Angew. Chem., Int. Ed., 2002, 41, 1363.

16 V. Lavallo, Y. Canac, A. De Hope, B. Donnadieu and G. Bertrand, Angew. Chem., Int. Ed., 2005, 44, 7236.

17 K. Vehlow, S. Maechling and S. Blechert, Organometallics, 2006, 25, 25.

18 (a) J. W. Sprengers, J. Wassenaar, N. D. Clement and K. J. Cavell, Angew. Chem., Int. Ed., 2005, 44, 2026; (b) N. D. Clement and K. J. Cavell, Angew. Chem., Int. Ed., 2004, 43, 3845.

19 (a) A. Furstner, O. R. Thiel and C. W. Lehmann, Organometallics, 2002, 21, 331; (b) A. Furstner, L. Ackermann, A. Beck, H. Hori, D. Koch, K. Langemann, M. Liebl, C. Six and W. Leitner, J. Am. Chem. Soc., 2001, 123, 9000.

20 G. Altenhoff, R. Goddard, C. W. Lehmann and F. Glorius, J. Am. Chem. Soc., 2001, 126, 15195.

21 (a) T. W. Funk, J. M. Berlin and R. H. Grubbs, J. Am. Chem. Soc., 2006, 128, 1840; (b) J. P. Morgan and R. H. Grubbs, Org. Lett., 2000, 2, 3153.

22 N. Marion, O. Navarro, J. Mei, E. D. Stevens, N. M. Scott and S. P. Nolan, J. Am. Chem. Soc., 2006, 128, 4101.

23 (a) M. J. Schultz, S. S. Hamilton, D. R. Jensen and M. S. Sigman, J. Org. Chem., 2005, 70, 3343; (b) C. M. Crudden and D. P. Allen, Coord. Chem. Rev., 2004, 248, 2247.

24 (a) R. H. Grubbs, Handbook of Olefin Metathesis, VCH-Wiley, Weinheim, 2003; (b) S. Beligny and S. Blechert, in $\mathrm{N}$ Heterocyclic Carbenes in Synthesis, ed. S. P. Nolan, WileyVCH Verlag GmbH \& Co. KGaA, Weinheim, 2004.

25 (a) I. Ozdemir, B. Yigit, B. Cetinkaya, D. Ulku, M. N. Tahir and C. Arici, J. Organomet. Chem., 2001, 633, 27; (b) S. Yasar, I. Ozdemir, B. Cetinkaya, J. L. Renaud and C. Bruneau, Eur. J. Org. Chem., 2008, 2142.

26 (a) I. Ozdemir, S. Yasar and B. Cetinkaya, Transition Met. Chem., 2005, 30, 831; (b) M. Yigit, B. Yigit, I. Ozdemir, E. Cetinkaya and B. Cetinkaya, Appl. Organomet. Chem., 2006, 20, 322. 
27 (a) S. Yaşar, K. J. Cavell, B. D. Ward and B. Kariuki, Appl. Organomet. Chem., 2011, 25, 374; (b) N. Gurbuz, I. Ozdemir, S. Demir and B. Cetinkaya, J. Mol. Catal. A: Chem., 2004, 209, 23.

28 I. Ozdemir, E. O. Ozcan, S. Gunal and N. Gurbuz, Molecules, 2010, 15, 2499.

29 L. Boubakri, K. Dridi, A. S. Al-Ayed, I. Ozdemir, S. Yasar and N. Hamdi, J. Coord. Chem., 2019, 72, 2080-2090.

30 N. Gürbüz, E. Ö. Özcan, İ. Özdemir, B. Çetinkaya, O. Şahin and O. Büyükgüngör, Dalton Trans., 2012, 41, 2330.

31 S. Yaşar, S. Çekirdek and İ. Özdemir, J. Coord. Chem., 2014, 67(7), 1236.

32 E. A. Baude and R. P. Linstead, J. Chem. Soc., 1954, 3544.

33 S. Yașar, E. O. Karaca, Ç. Șahin, İ. Özdemir, O. Șahin and O. Büyükgüng, J. Organomet. Chem., 2015, 789-790, 1.

34 (a) M. Poyatos, J. A. Mata, E. Falomir, R. H. Crabtree and E. Peris, Organometallics, 2003, 22, 1110; (b) R. Corbean, M. Sanau and E. Peris, Organometallics, 2007, 26, 3492; (c) D. Gnanamgari, A. Moores, E. Rajaseelan and R. H. Crabtree, Organometallics, 2007, 26, 1226; (d) R. Castarlenas, M. A. Esteruelas and E. Onate, Organometallics, 2008, 27, 3240; (e) D. Gnanamgari, E. L. O. Sauer, N. D. Schley, C. Butler, C. D. Incarvito and R. H. Crabtree, Organometallics, 2009, 28, 321; (f) S. Kuhl, R. Schneider and Y. Fort, Organometallics, 2003, 22, 4184.

35 N. Tabet, Acetylcholinesterase inhibitors for Alzheimer's disease: anti-inflammatories in acetylcholine clothing!, Age Ageing, 2006, 35(4), 336.
36 O. Ismail, G. Yetkin, Ö. Özlem, K. Murat, D. Henri and B. Christian, Eur. J. Inorg. Chem., 2010, 1798.

37 (a) M. K. Kathiravan, A. B. Salake, A. S. Chothe, P. B. Dudhe, R. P. Watode, M. S. Mukta and S. Gadhwe, Bioorg. Med. Chem., 2012, 20, 5678; (b) B. Zhai and X. Lin, Curr. Pharm. Biotechnol., 2011, 12, 1255.

38 S. K. Kalauni, M. I. Choudhary, A. Khalid, M. D. Manandhar, F. Shaheen and G. M. B. Atta-ur-Rahman, New cholinesterase inhibiting steroidal alkaloids from the leaves of Sarcococca coriacea of Nepalese origin, Chem. Pharm. Bull., 2002, 50, 1423.

39 W. A. T. Atta-ur-Rahman, S. A. Nawas and M. I. Choudhary, New cholinesterase inhibiting bisbenzylisoquinoline alkaloids from Cocculus pendulus, Chem. Pharm. Bull., 2004, 52, 802.

40 (a) W. Ahmad, B. Ahmad, M. Ahmad, Z. Iqbal, M. Nisar and M. Ahmad, In vitro inhibition of acetylcholinesterase, butyrylcholinesterase and lipoxygenase by crude extract of Myricaria elegans Royle, J. Biol. Sci., 2003, 11, 1046; (b) R. Re, N. Pellegrini, A. Proteggente, A. Pannala, M. Yang and C. Rice-evans, Free Radical Biol. Med., 1999, 26(10), 1231.

$41 \mathrm{X}$. Song, et al. Development of PLGA Nanoparticles Simultaneously Loaded with Vincristine and Verapamil for Treatment of Hepatocellular Carcinoma, J. Pharm. Sci., 2010, 99, 4874.

42 E. J. De Beer and M. B. Sherwood, The paper-disc agar plate method for the assay of antibiotic substances, J. Bacteriol., 1945, 50, 459. 